\title{
Neolithic water management and flooding in the Lesser Caucasus (Georgia)
}

\author{
V. Ollivier ${ }^{\text {a, }}{ }^{*}$, M. Fontugne ${ }^{\text {a }}$, C. Hamon ${ }^{\text {b }}$, A. Decaix ${ }^{c}$, C. Hatté ${ }^{\text {d }}$, M. Jalabadze ${ }^{e}$ \\ a Aix Marseille Univ, CNRS, Minist Culture, LAMPEA, Aix-en-Provence, France \\ ${ }^{\mathrm{b}}$ CNRS, UMR 8215 Trajectoires, Maison de l'arch'eologie, 21 all'ee de l'Universit'e, 92023, Nanterre Cedex, France \\ ${ }^{c}$ UMR 7209 - Arch' eozoologie, Arch'eobotanique: Soci'et' es, Pratiques et Environnements, Mus' eum National d'Histoire Naturelle et CNRS, Paris, \\ France ${ }^{\mathrm{d}}$ Laboratoire des Sciences du Climat et de l'Environnement UMR 8212 CNRS-CEA-UVSQ Domaine du CNRS, 91198, Gif sur Yvette, France \\ e Georgian National Museum, Rustaveli Av. 3, Tbilisi 5, Georgia
}

\begin{abstract}
River management is generally thought to have started at $5500 \mathrm{cal}$. BC within the development of eastern Neolithic societies. In the Lesser Caucasus, evidence of early river management has been discovered around the famous Neolithic sites of Shulaveri, Gadachrili Gora, and Imiris Gora in Georgia. Here we report a preliminary data set indicating that river management was set up at $5900 \mathrm{cal}$. $\mathrm{BC}$ leading to the flooding, destruction, and local abandonment of the hydraulic infrastructures of the Gadachrili village between 5750 and $5430 \mathrm{cal}$. BC. The hydraulic infrastructures were developed during a more humid period encompassing the $8200 \mathrm{cal}$. BP $(6200 \mathrm{cal}$. BC) climatic event, probably to optimize agricultural yield. It potentially led to the first prehistoric engineering accident for which there is evidence, which

may have been followed by the reorganisation of the occupation and/or to architectural modifications.
\end{abstract}

\section{Introduction}

Despite intensive surveys, fieldwork, and excavations conducted in the last decade by international teams, cross-research between archaeology and geomorphology is limited in the Lesser Caucasus, a mountainous region at the crossroads of Europe, Asia, and Africa. Excavations within the framework of a Caucasian-European joint project encompass some of the most important Neolithic sites of the Lesser Caucasus in Armenia (Badalyan et al., 2010; Chataigner et al., 2014), Azerbaijan (Lyonnet et al., 2012, 2017; Helwing and Aliyev, 2017) and Georgia (Hamon et al., 2016; Hansen and Mirtskhulava, 2017; Hansen and Ulrich, 2017). In the last decade, understanding of the Neolithisation of the Lesser Caucasus has grown. The dates of its emergence have been defined to the turn of the 6th millennium $\mathrm{BC}$, with regional specificities identified

\footnotetext{
* Corresponding author.

E-mail address: ollivier@mmsh.univ-aix.fr (V. Ollivier).
}

(Badalyan et al., 2010; Guliyev and Nishiaki, 2010; Lyonnet et al., 2012; Hamon et al., 2016; Chataigner et al., 2014). The development of Neolithic societies in the Middle East and Central Asia was always closely linked to the management of water resources. This is illustrated by prehistoric water management in the Jordan Valley (Mithen, 2010; Fujii, 2007). There, the Neolithic is a key period of significant development, leading to the birth and prosperity of the first urban communities of the Early Bronze Age. The first hydraulic installations, intended, among other things, for the irrigation of cereal crops, appeared in the 6th millennium BC in Mesopotamia (Adams, 1974).

Defining clear prehistoric water management structures in the landscape and in stratigraphy is a difficult task due to their low archaeological visibility. In the Lesser Caucasus, signs of small artificial channel structures have been observed during the excavations of some Neolithic sites in Azerbaijan (Lyonnet et al., 2012, 2016; Ollivier et al., 2016) and Georgia (Hansen and Mirtskhulava, 2012), but their role has not been clearly defined as they have 
revealed limited evidence for runoff both through stratigraphy and sedimentology. With surface water management, channels vary widely in shape, size, and hydraulic characteristics (Bishop et al., 1967; Aurenche, 1982). They were frequently built to divert perennial and/or non-perennial river flows (Huckleberry et al., 2012; Huckleberry and Rittenour, 2014; Doolittle, 2011, Van Andel et al., 1990; among others). Their possible association with irrigation is also difficult to determine. The interplay between the need to respond to and to overcome certain natural constraints (climate, lithology ...), and the diversity of cultural phenomena specific to different societies, makes the links between water management structures and the need for irrigation ambiguous (Staubwasser and Weiss, 2006; Coombes and Barber, 2005; Hassan, 2011; Cauvin, 1978).

Since the 1960s, some archaeological operations have been developed in Gadachrili Gora, a Georgian Neolithic site from the Southern Caucasus Shulaveri-Shomu culture (Hamon et al., 2016). In 2013, geomorphology research was developed in the framework of archaeological investigations in a joint project between the Georgian National Museum and the French National Centre for Scientific Research (Hamon et al., 2016). Gadachrili Gora is part of the Shulaveri group sites, located close to the modern village of Imiri in Kvemo-Kartli. It is close to the sites of Shulaveri, Imiris, and Dangreuli Gora that have provided the first chronology for the area as well as most of our knowledge on the first Neolithic culture and agriculture in Georgia (Kiguradze, 1986; Hamon, 2008).

We present here our results pertaining to the discovery of a series of channels linked to a probable Neolithic water management system discovered in the vicinity of Gadachrili Gora, diverting the flow of the Shulaveri Ghele, a tributary of the Khrami river. In support of this discovery, we also briefly present an example of a Neolithic channel under study in the archaeological site of Mentesh Tepe (Middle Kura Valley, Azerbaijan).

Our results mainly raise the question of the links between climate, autocyclic phenomena, and development of water management structures in a region poorly known in this field, through a study integrating radiocarbon dating, geomorphology, archaeology, and palaeobotany of carpological remains. In spite of these different environmental, technological-typological, and topographical indicators, we carried out isotopic analyses on the seeds in order to characterise or not the occurrence of irrigation. Previous studies around the Mediterranean basin show that the carbon isotopic composition of cereal grain (mainly barley and wheat) can be used to evaluate the occurrence of irrigation practices, increasing aridity, or the impact of drought on Neolithic and Bronze Age societies (Araus et al., 1997a; b; Flohr et al., 2011; Wallace et al., 2013). In contrast, very little data of this type are available for the Lesser Caucasus where irrigation practices are not yet clearly identified for Prehistory.

Through this work we would like to highlight the possibility of the development in the Caucasus of the oldest known water management practices. In addition, we present an original focus on the potential effects of torrential palaeo-floods on Neolithic water management structures and riparian habitats.

\section{Regional setting}

\subsection{Environmental context}

Like the well-known Neolithic sites of Shulaveri Gora, Imiris Gora, and Aruchlo, Gadachrili Gora is located in the Kvemo-Kartli Plain dominating the Marneuli-Kura depression. The mountains surrounding the site show altitudes between 450 and 1080 masl and consist mainly of Cretaceous limestones, sandstones, and breccias, and of Upper Pliocene-Middle Quaternary basalts and andesites (Fig. 1). Present-day local climate is ranked, according to the Köppen classification (Peel et al., 2007), as warm-humid continental (Dfa). The average annual temperature is $13.4{ }^{\circ} \mathrm{C}$ and about $472 \mathrm{~mm}$ of precipitation fall annually (Climate-Data.org). This eastern part of Georgia has the driest climate of the country (Kvinikadze et al., 2006). The vegetation mainly consists of thornbush steppe type present on slopes areas, where plants develop in former forest areas. The dominant plants of this type of steppe vegetation are Paliurus spina-christi and steppe grain species (Bothriochloa ischaemum, Festuca ovina, Stipa pulcherrima). Here and there separate specimens of field maple and nettle tree (Celtis caucasica) can also be found (Nakhutsrishvili, 2012).

\subsection{The Shulaveri and Khrami hydrosystem}

This mountainous and steppic landscape is also cut across by a well-developed hydrosystem consisting of the Khrami river and its local tributary, the Shulaveri river (Fig. 1). The Khrami river is a right-hand side tributary to the Kura river (Fig. 1). It originates from a spring, located on the southern slope of the Trialeti range at an altitude of 2422 masl. With a length of $201 \mathrm{~km}$ and a watershed of $8340 \mathrm{~km}^{2}$, the Khrami river has also two main tributaries, the Debeda and the Mashavera rivers. The hydrological regime is characterised by one significant spring flood. In other periods of the year, the water level is mostly low and occasionally disrupted by summer and autumn high waters. The annual discharge rates fluctuate from 7.02 to $51.7 \mathrm{~m}^{3} / \mathrm{s}$, depending on location (U.S. Agency for International Development \& Development Alternatives Inc., 2002). The Shulaveri river originates from the joining of two springs on the northern slope of the Lokhi range at an altitude of 1190 masl and joins the Khrami from the right bank. The total length of the river is $38 \mathrm{~km}$, with a catchment area of $117 \mathrm{~km}^{2}$. Arriving in the plain, its average many-year discharge $\left(0.44 \mathrm{~m}^{3} / \mathrm{sec}\right)$ entirely runs to irrigation channels. The Shulaveri is not currently a permanent river. Both rivers, Khrami and Shulaveri, are generally fed by rain water (40-45\% of annual discharge), snow water (20-25\%), and ground waters (25-30\%) (United Nations, 2011).

\subsection{Archaeological setting}

The site of Gadachrili Gora (363 m asl., $41^{\circ} 23^{\prime}$ N, $44^{\circ} 49^{\prime}$ E, Fig. 2) forms part of a series of Neolithic settlements (tell) in the KvemoKartli Plain (Hamon et al., 2016), distributed along a nonperennial tributary of the Khrami river, the Shulaveris Ghele (Fig. 1). It occupies a more or less central position between the sites of Shulaveris Gora, Imiris Gora, and Dangreuli Gora (totally destroyed today). The excavation of the latter in the 1970s provided the first chronological frame and knowledge of the Neolithic Shulaveri-Shomu culture in Georgia (Kiguradze, 1986). The middle part of the site is actually incised by the river Shulaveris Ghele. As a result, two thirds of the former settlement has been completely destroyed. The south-eastern side of the site and a small quantity of cultural deposits on the right bank of the river have survived. The radiocarbon dating places the first levels of this tell between 5920 and $5720 \mathrm{cal}$ BC (Hamon et al., 2016). The overall archaeological stratigraphy consists of two horizons showing different types of settlement organisation. Evidence from the deepest occupation levels suggests a high-density occupation in the settlement, with complex episodes of destruction and rebuilding. The coexistence of different building techniques in the two horizons has to be noted. The high number of storage structures and the discovery of organised built spaces dedicated to storage raise many questions about the status of the site, the organisation of agricultural practices, and the relationship of these populations to the hydrographic network within the area. In addition, the spatial distribution of the 

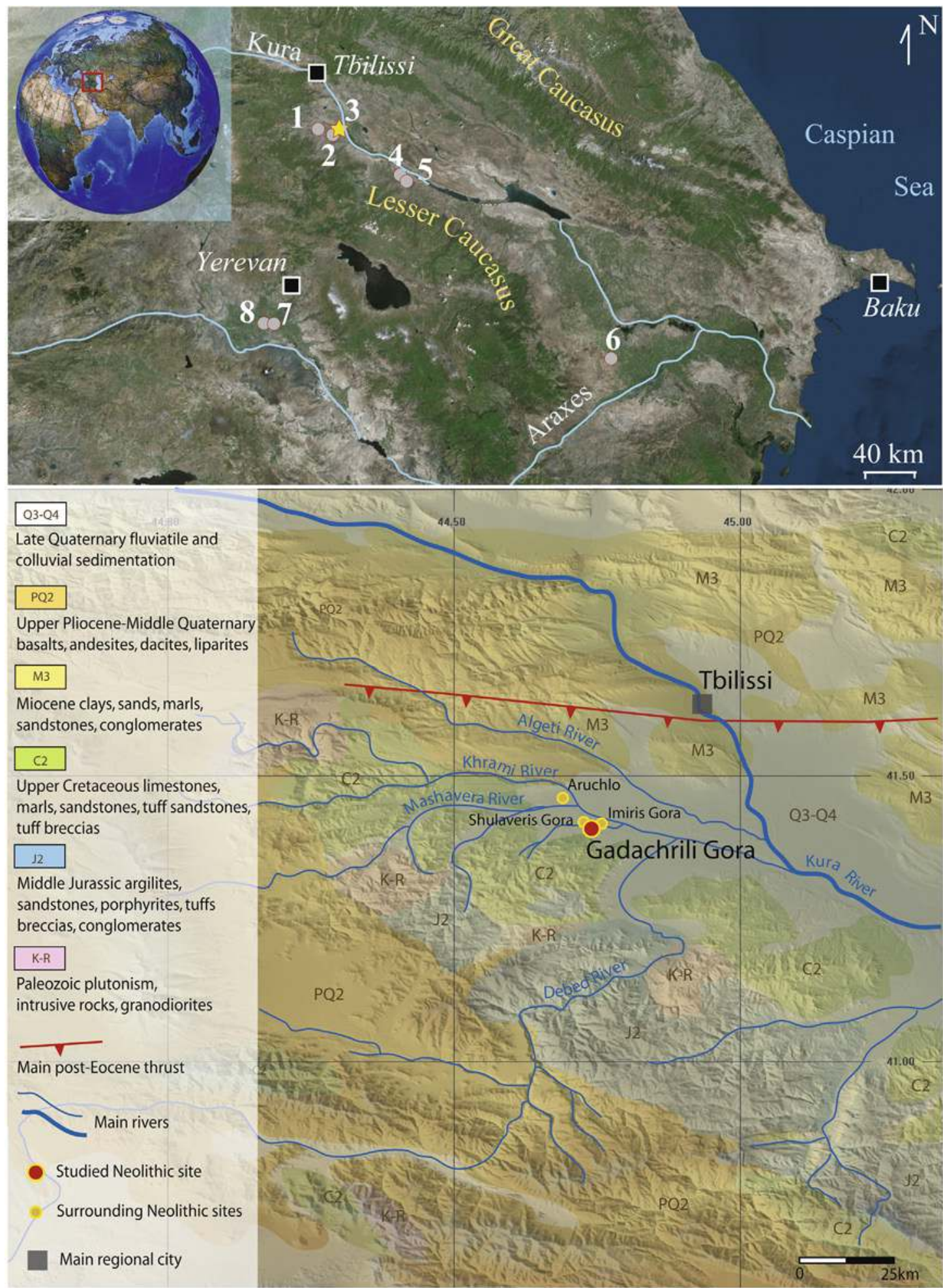

Fig. 1. General context of Gadachrili Gora archaeological site. Top panel: Numbers corresponds to the main Neolithic site recently studied in the region with: 1) Aruchlo (Hansen and Mirtskhulava, 2012); 2) Shulaveri Gora (Kiguradze, 1986); 3) Gadachrili Gora (Hamon et al., 2016); 4) Goy Tepe, (Guliyev and Nishiaki, 2010); 5) Mentesh Tepe (Lyonnet et al., 2016); 6) Kamil Tepe (Helwing and Aliyev, 2017); 7) Aratashen (Chataigner et al., 2014); 8) Aknashen (Badalyan et al., 2010). Bottom panel: Geological context and closest Neolithic sites in the vicinity of Gadachrili Gora archaeological site. 

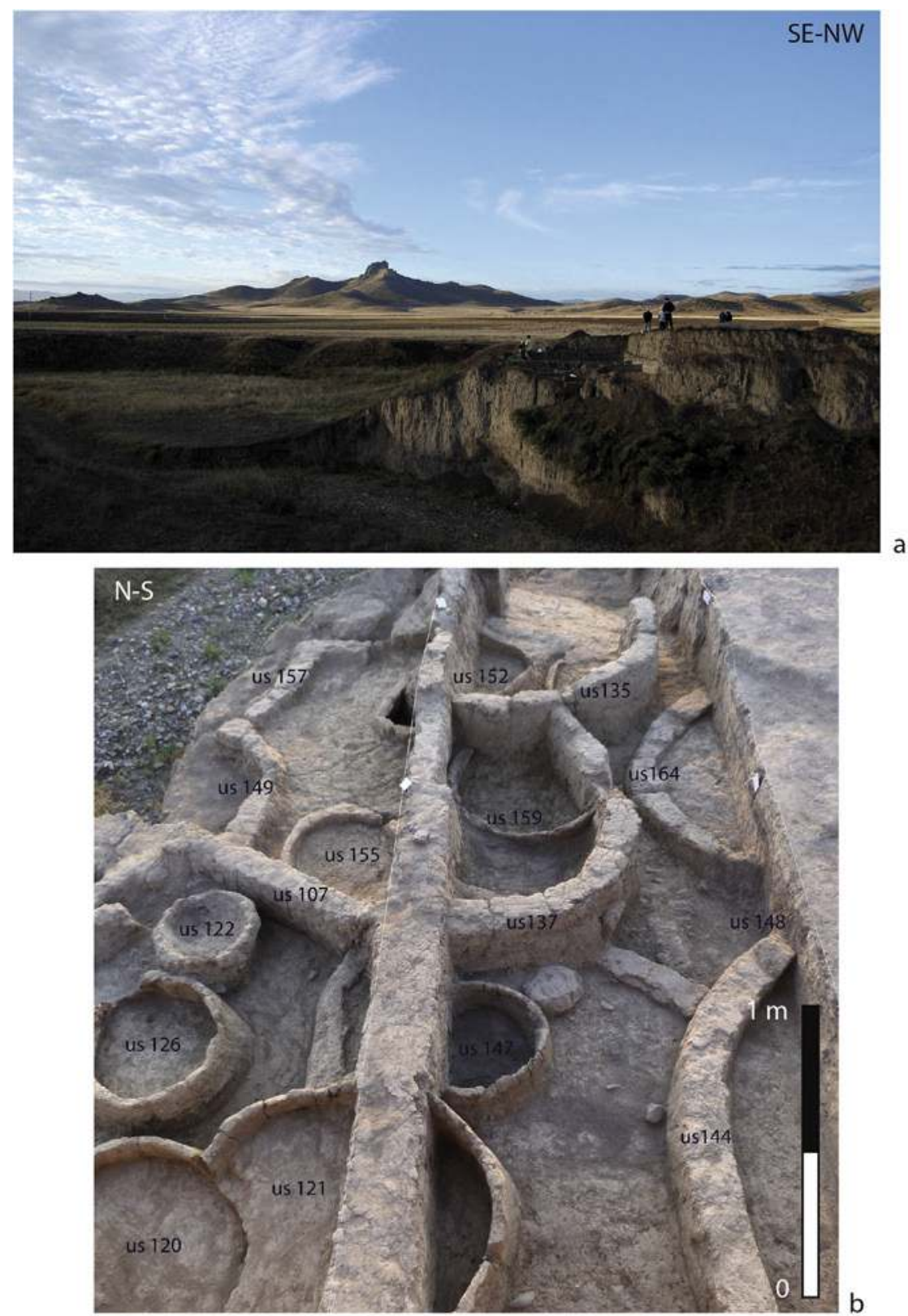

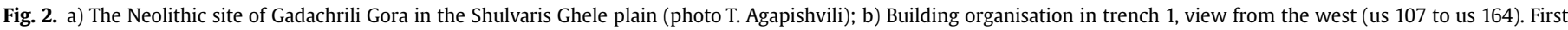

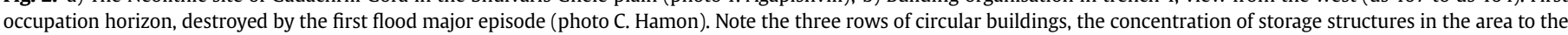

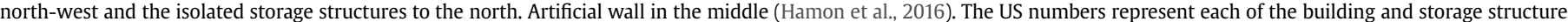
excavated.

settlements offers an interesting window to the study of Neolithic territories and their socio-economic organisation.

\section{Materials and methods}

\subsection{Geomorphology}

We conducted upstream-downstream research on the Shulaveri Ghele during our previous work in the Middle Kura valley defining the inland impact of the Caspian Sea relative level changes (Ollivier and Fontugne, 2012; Ollivier et al., 2015, 2016; Ollivier et al., 2015). The alluvial formation organisation was determined along the Shulaveri Ghele river. Additionally, four stratigraphic sections framing the archaeological excavation of Gadachrili (named C1 to
C4) were studied in depth. Their stratigraphic correlation and link with the archaeological site were established on an upstreamdownstream longitudinal section of $300 \mathrm{~m}$. Once the morphosedimentary and sedimentary sequence was recorded, the samples for radiocarbon dating were taken from the stratigraphic sequence ruptures, at the base and at key positions in the anthropic channel infilling, and at different levels of the alluvial sedimentary formations, in order to obtain an event chronology (Ollivier, 2009). The dynamics and variations of the fluvial system as well as the sediment transport energy curve were determined using macrofacies sedimentological characteristics (adapted from Hjulström, 1935, Neill, 1967, 1968, Wu et al., 1973, Miall, 1988) and a semiquantitative analysis of the sediment facies (Bonham-Carter, 1965, Malkowski and Hoffman, 1979, McLaren and Bowles, 1985) 
described in Ollivier et al. (2015). For the anthropogenic channels, the curve of erosion and deposition critical speed were defined according to the work of Hjulström (1935), Sundborg (1956), (1967), Church and Gilbert (1975), Koster (1978), Costa (1983), and Petit (1988). Their imagery was treated by chromatic filters under Adobe Photoshop CS5 extended software. The natural palaeotalweg of the Shulaveri river was determined during fieldwork and by satellite images under Google Earth Pro. To avoid error with possible surficial eroded traces of modern earth channels, a series of Soviet (sheets K-38-XXI and K-38-90-G), German (sheet K38$\mathrm{XXI}$ ), and United States (sheet NK 38-8) topographic military maps ( $1: 42,000 ; 1: 50,000 ; 1: 200,000$ and $1: 250,000)$ covering the years 1920-1942-1951, 1982, and 1984 were used to verify the former existence of such structures.

\subsection{Radiocarbon dating}

A total of thirteen radiocarbon measurements were performed on several charcoal samples $(0.5-1 \mathrm{~cm}$ of diameter), on palaeosol organic matter and on sedimentary organic matter (Table 1 ). Due to the rapid sedimentation rate of the terraces, pedogenesis is greatly reduced and organic matter is buried rapidly and homogeneously without a significant turnover effect. Thus, the carbon isotopic signal of palaeosols might only be slightly altered and the measured ${ }^{14} \mathrm{C}$ activity may reflect that of the vegetation or the humus (O'Leary, 1988; Hatté et al., 1998; Hatté et al., 2001a, 2001b; Lang et al., 2003). Nevertheless, the sedimentary organic matter which was dated was a mix of sediment fluvially redeposited with remains of vegetation contemporaneous with the deposit. Consequently, these ages must be considered as slightly too old. Concerning sample SacA39133/Gif-13112, the dated organic carbon is also a mixture of sedimentary organic matter from the late Pleistocene substrate and organic matter deposited when the channel was operating. All samples were prepared following a standard procedure (Délibrias, 1985) at the LSCE Laboratory (Gif sur Yvette). Charcoal samples were treated following the ABA (Acid: Base: Acid) method. Sediments were then sieved using meshes of $250 \mu \mathrm{m}$ to remove possible roots. The fine fraction was decarbonated with $\mathrm{HCl} 0.6 \mathrm{~N}$ (Gauthier and Hatté, 2008), rinsed, dried at $50^{\circ} \mathrm{C}$, and homogenised. The samples were then combusted at $900^{\circ} \mathrm{C}$ in an evacuated quartz tube with copper oxide and silver foil. Radiocarbon activity was measured using AMS facilities of
LMC14 (ARTEMIS) at Saclay. Conventional ${ }^{14} \mathrm{C}$ ages are expressed in years before present (B.P.), with $1 \sigma$ error. Ages were calibrated using OxCal v4 2.3 Bronk Ramsey and Lee (2013): r5 IntCal 13 atmospheric curve (Reimer et al., 2013). Calibrated dates are given with a level of confidence of $95.4 \%$ ( 2 sigma range). The $\delta^{13} \mathrm{C}$ values used for conventional age calculation are obtained from accelerator measurement and include carbon isotope fractionation due to graphitisation and ion beams during measurements. They have no palaeoenvironmental significance.

\subsection{Archaeology}

The archaeological data are from the fieldwork and excavations conducted over the past few years in the context of the GeorgianFrench collaboration (Hamon et al., 2016) in Gadachrili Gora and surrounding area. The data of the Caucasia GIS and Navigasig developed by the CNRS and the BRGM (Copyright BRGM, 20012009, Courcier, 2010) are used to place the archaeological sites of the Lesser Caucasus and the geomorphological evolution in the context of the regional development of the prehistoric societies.

\subsection{Palaeobotany}

The archaeobotanical analysis undertaken in Gadachrili Gora allowed the study of 64,300 seeds and fruit and 675 charcoal fragments. The macro-remains were extracted from the soil using a flotation machine with a sieve mesh size of $0.5 \mathrm{~mm}$. Seeds and fruit were sorted out using a binocular microscope allowing $\times 10$ magnification. They were identified with the help of a reference collection of Near-Eastern seeds and comparitive atlases. Charcoal fragments were studied using a reflected light microscope (x50x1000) (Benkova and Schweingruber, 2004, Cappers et al., 2009, Cappers and Bekker, 2013, Jacomet, 2006, Neef et al., 2011, Nesbitt and Goddard, 2006, Parsa Pajouh et al., 2001, Schweingruber, 1990, Schweingruber et al., 2011).

\subsection{Isotopic analyses on carpological remains}

Seed samples are carbonate-free. No chemical treatment was applied. The burnt seeds were only reduced to a homogeneous powder prior to analysis. Bulk sample $\mathrm{C}$ and $\mathrm{N}$ content were determined using an elemental analyser (Flash EA 1112) and the

Table 1

Radiocarbon dating in the studied sections of Gadachrili, Mashavera River and Mentesh Tepe.

\begin{tabular}{|c|c|c|c|c|c|c|}
\hline $\mathrm{N}^{\circ}$-Laboratory & Section and Level & Location GPS & Nature & Age BP & Age cal. BP & Age cal. BC/AD \\
\hline \multicolumn{7}{|l|}{ Gadashrili (Shulaveri River) } \\
\hline SacA39135/Gif-13086 & $\mathrm{C} 3 ; 6 \mathrm{~b}$ & $41^{\circ} 23,453 \mathrm{~N} ; 44^{\circ} 49,242 \mathrm{E}$ & Sediment & $1525 \pm 30$ & $1425-1347$ & 525-603 cal AD \\
\hline SacA37799/Gif-13086 & $\mathrm{C} 3 ; 6 \mathrm{~b}$ & $41^{\circ} 23,453 \mathrm{~N} ; 44^{\circ} 49,242 \mathrm{E}$ & Sediment & $1560 \pm 30$ & $1529-1387$ & $421-563$ cal AD \\
\hline SacA37091/Gif-13063 & $\mathrm{C} 2 ; 5$ & $41^{\circ} 23,403 \mathrm{~N} ; 44^{\circ} 49,317 \mathrm{E}$ & Charcoal & $4600 \pm 30$ & $5329-5284$ & $3380-3335$ \\
\hline SacA37092/Gif-13064 & $\mathrm{C} 3 ; 2 \mathrm{a}$ & $41^{\circ} 23,453 \mathrm{~N} ; 44^{\circ} 49,242 \mathrm{E}$ & Charcoal & $7045 \pm 40$ & $7954-7794$ & $6005-5845$ \\
\hline SacA37800/Gif-13087 & $\mathrm{C} 3 ; 2 \mathrm{c}$ & $41^{\circ} 23,453 \mathrm{~N} ; 44^{\circ} 49,242 \mathrm{E}$ & Sediment & $7745 \pm 40$ & $8592-8433$ & $6643-6484$ \\
\hline SacA39136/Gif-13087 & $\mathrm{C} 3 ; 2 \mathrm{c}$ & $41^{\circ} 23,453 \mathrm{~N} ; 44^{\circ} 49,242 \mathrm{E}$ & Sediment & $7765 \pm 45$ & $8609-8429$ & $6660-6480$ \\
\hline SacA37798/Gif-13085 & $\mathrm{C} 1 ; 13$ & $41^{\circ} 23,422 \mathrm{~N} ; 44^{\circ} 49,334 \mathrm{E}$ & Sediment & $8140 \pm 40$ & $9141-9000$ & $7192-7051$ \\
\hline SacA39133/Gif-13112 & C $3 ; 1$ & $41^{\circ} 23,453 \mathrm{~N} ; 44^{\circ} 49,242 \mathrm{E}$ & Sediment & $8305 \pm 45$ & $9441-9194$ & $7492-7245$ \\
\hline SacA37797/Gif-13084 & $\mathrm{C} 1 ; 2$ & $41^{\circ} 23,422 \mathrm{~N} ; 44^{\circ} 49,334 \mathrm{E}$ & Sediment & $11,620 \pm 50$ & $13,564-13334$ & $11,615-11385$ \\
\hline \multicolumn{7}{|l|}{ Gadashrili Gora } \\
\hline OS-63262 & Horizon 1 & $41^{\circ} 23,436 \mathrm{~N} ; 44^{\circ} 49,258 \mathrm{E}$ & Charcoal & $6510 \pm 110$ & $7591-7242$ & $5642-5293$ \\
\hline LTL13223A & Horizon 2 & $41^{\circ} 23,436 \mathrm{~N} ; 44^{\circ} 49,258 \mathrm{E}$ & Charcoal & $6860 \pm 45$ & $7792-7608$ & $5843-5659$ \\
\hline OS-63260 & Horizon 2 & $41^{\circ} 23,436 \mathrm{~N} ; 44^{\circ} 49,258 \mathrm{E}$ & Charcoal & $6890 \pm 40$ & $7829-7656$ & $5880-5707$ \\
\hline LTL13000A & Horizon 2 & $41^{\circ} 23,436 \mathrm{~N} ; 44^{\circ} 49,258 \mathrm{E}$ & Charcoal & $6941 \pm 45$ & $7860-7678$ & $5911-5729$ \\
\hline \multicolumn{7}{|l|}{ Mashavera River/Aruchlo } \\
\hline SacA $33,000 /$ Gif- 13,027 & KUR GEO 12/11 & $41^{\circ} 26,764 \mathrm{~N} ; 44^{\circ} 41,603 \mathrm{E}$ & Charcoal & $1930 \pm 30$ & $1946-1820$ & $4-130$ cal AD \\
\hline \multicolumn{7}{|l|}{ Mentesh Tepe } \\
\hline SacA37081/Gif-13053 & US 574 & $40^{\circ} 56,514 \mathrm{~N} ; 45^{\circ} 49,986 \mathrm{E}$ & Charcoal & $6795 \pm 45$ & $7694-7574$ & $5745-5625$ \\
\hline
\end{tabular}


${ }^{13} \mathrm{C} /{ }^{12} \mathrm{C}$ ratio was obtained using the online continuous EA coupled with an Isotopic Ratio Mass Spectrometer (Finigan Delta $+\mathrm{XP}$ ). The results are expressed in $\delta^{13} \mathrm{C}$ per mil (\%o) versus the international standard V-PDB (Vienna Pee Dee Belemnite). All the analyses were performed in triplicate. Mean value is associated to uncertainty equal to the maximum between the standard deviation and the chisquare reduced error. This accounts for both measurement uncertainty and sample heterogeneity.

\section{Results}

\subsection{Alluvial units and anthropogenic-type channels morphology}

The site of Gadachrili Gora is located on a composite sedimentary fan formation locally grouping the levels T1 to T4 of the main alluvial terrace system defined in the region (Ollivier and Fontugne, 2012; Ollivier et al., 2015, 2016, Suchodoletz et al., 2016), which is forming an upstream part of the Kura river hydrosystem (Fig. 3). The torrential nature of the Shulaveri river is clearly expressed in the sedimentary facies observed in the surrounding natural sections. The studied section, named $\mathrm{C} 1, \mathrm{C} 2, \mathrm{C} 3$, and $\mathrm{C} 4$, frame the archaeological site of Gadachrili from upstream to downstream (Fig. 3). The formation reaches around seven to $8 \mathrm{~m}$ of thickness. The organisation of the different deposit phases shows: 1) a first Lateglacial phase dated to the beginning of the sequence around $11,620 \pm 50$ BP in C1 $(13,450$ cal. BP, 11,615 cal. BC, Table 1 and Figs. 3-7) with low energy sedimentation (silts and sands) punctuated by the development of hydromorphic soils and torrential detrital discharges (pebbles, gravels, and sands); 2) more pronounced torrential features (pebbles, gravels, and sand deposits with small incisions and/or erosive contact) from the beginning of the Holocene around $8140 \pm 40$ and $8305 \pm 45$ BP (9076 cal. BP, 7121 cal. BC and 9327 cal. BP, 7368 cal. BC in C1 and C3) as seen in regional studies (Ollivier and Fontugne, 2012; Ollivier et al., 2015, 2016, Suchodoletz et al., 2016) but with some short soil development; 3 ) a second Holocene torrential unit with pebbles, sands, and erosive contact, as well as overflow silts and the development of soils (sometimes containing bones and charcoal) laterally to the active watercourse and dated around $4600 \pm 30 \mathrm{BP}$ in C2 (5322 cal. BP, 3292 cal. BP); 4) a thick dark brown soil developed in the final sections of the regional stratigraphic sequences dated around $1930 \pm 30 \mathrm{BP}(1883 \mathrm{cal}$. BP, $67 \mathrm{cal}$. AD) in the Mashavera river (around the Neolithic archaeological site of Aruchlo, Fig. 8), the latter showing the same sedimentary sequence succession (Lateglacial silts and hydromorphic soils followed by pebbly Holocene torrential units covered by the brown soil) as in section $\mathrm{C} 3$ of the Shulaveri Ghele river with a soil dated between $1560 \pm 30 \mathrm{BP}$ and $1525 \pm 30$ BP (1466 cal. BP, 492 cal. AD, and 1410 cal. BP, 513 cal. AD).

Despite the interest concerning the Postglacial morphosedimentary organisation in this area (Suchodoletz and Faust, 2017), the most striking geoarchaeological finding concerns the existence of anthropogenic type excavations in the soft sediments of the Lateglacial - Holocene sequences (Figs. 6 and 7). The sediment at the base of these excavations contains pottery and bone debris. The local organisation of these diggings, that look like canals, is made visible in a stratigraphic section by the incision of the Shulaveri river in the site of Gadachrili (Figs. 6, 7 and 9). Covered by $2.5 \mathrm{~m}$ of historical period deposits, these artificial channels are not visible on the surface. Section C4 (Fig. 7), in the left bank, shows one major channel divided in three smaller well-dimensioned canals in section C3 on the right bank (Figs. 6 and 9). The preserved canal morphology of section C3 is of two distinct types, parabolic and trapezoidal, with dimensions varying between 0.75 and $1.5 \mathrm{~m}$ of depth and $1.5,3$, and $5.5 \mathrm{~m}$ width. With a unique trapezoidal morphology, the hydraulic structure observed in section C4 is of
$1.5 \mathrm{~m}$ deep and more than $15 \mathrm{~m}$ wide. The radiocarbon dating obtained (Table 1) in the channels of section C3 (Figs. 6 and 9) range from $7765 \pm 45 \mathrm{BP}$ and $7745 \pm 40 \mathrm{BP}(8542 \mathrm{cal}$. BP and $8520 \mathrm{cal}$. BP, $6622 \mathrm{cal}$. BC and $6563 \mathrm{cal}$. BC) to $7045 \pm 40 \mathrm{BP}(7884 \mathrm{cal}$. BP, 5925 cal. BC). The oldest date, issued from a measurement on organic matter contained in the sediments (SOM), is probably too old since it represents a mix with Lateglacial sediments from the bottom of the channel (or from bank erosion). Therefore, the $7045 \pm 40$ BP date obtained from charcoal samples seems to be the most coherent. The hydraulic structure of section C4 remains unfortunately undated for technical reasons (poor preservation of the sampled charcoal). But the geometry, the sedimento-stratigraphy, the lithic and ceramic finds, and the stratigraphical connection with the archaeological excavation (horizon 2, Fig. 3, Fig. S1, and Hamon et al., 2016) allow us to establish these different anthropogenic channels as contemporaneous. In addition, the closeness between our stratigraphic and absolute dating results indicates that both the occupation (horizon 2 dated at $6941 \pm 50 \mathrm{BP}, 7768 \mathrm{cal}$. BP/ 5920 cal. BC, Fig. 3) and the hydraulic structure were probably developed during the same period. Another example of anthropogenic type channels was also found in Mentesh Tepe (Lyonnet et al., 2016; Ollivier et al., 2016). In this excavation, more modest-sized ditches than in Gadachrili were filled with alluvial material or runoff. The strongest evidence (Fig. 10) is the parabolic canal type that is chronologically framed between 5882 cal. BC (bottom of the archaeological excavation, Lyonnet et al., 2016) and 5683 cal. BC (level sealing the channel, Table 1 and Fig. 10). Despite the quality and the increasing number of excavations in recent decades, this is the first time in the Lesser Caucasus that hydraulic structures dating from the Neolithic have been clearly identified and dated in association with human settlements.

\subsection{Palaeohydrology}

We did not actually calculate the hydraulic components in Mentesh Tepe because the river network supplying the anthropic channel was different to today's network and needs further physiographic reconstruction (Ollivier et al., 2015, 2016). In Gadachrili, a detailed analysis of the sequences filling the channels C3 and C4 makes it possible to relatively define the flow velocities and to trace the history of their use (Fig. 11). However, it is important to note that, like the changes in the initial shape of the canals (particularly visible by the asymmetry in the right-side channel of section C3), their fill reflects only a fragmentary history of their functioning due to cleaning practices and high-energy events (Purdue and Berger, 2015). The choice of sampling the undisturbed stratigraphic decantation units was decisive in the dating of these structures. Although with different channel morphologies, the hydraulic structures of Gadachrili display the same global hydrologic, stratigraphic evolution, and morphogenic trends (Fig. 11) in their sedimentary fill. In each case, the presence of soil enriched with ash and organic matter indicates probable cleaning of vegetation and stagnant water that can be used as stratigraphic reference levels. These markers visible in the same stratigraphic position in each of the structures allow us to say that these channels have probably worked at the same time, and according to the three ${ }^{14} \mathrm{C}$ dates obtained, for a maximum period of 50-100 years. The values obtained by using the Hjulström method under natural hydrology (Fig. 11) range from $>0.1 \mathrm{~cm} \mathrm{~s}^{-1}$ for the least dynamic flows (Lateglacial) and $>100 \mathrm{~cm} \mathrm{~s}^{-1}$ for Holocene floods. It is generally admitted that in modern earth channels (much larger and more constantly supplied by water than those of Gadachrili), the permissible velocities are between 0.60 and $1 \mathrm{~m} \mathrm{~s}^{-1}$ (Soutter et al., 2007). The flow velocity must also exceed $0.5 \mathrm{~m} \mathrm{~s}^{-1}$ to avoid the formation of deposits in the channels and to be less than $2.5 \mathrm{~m} \mathrm{~s}^{-1}$ 


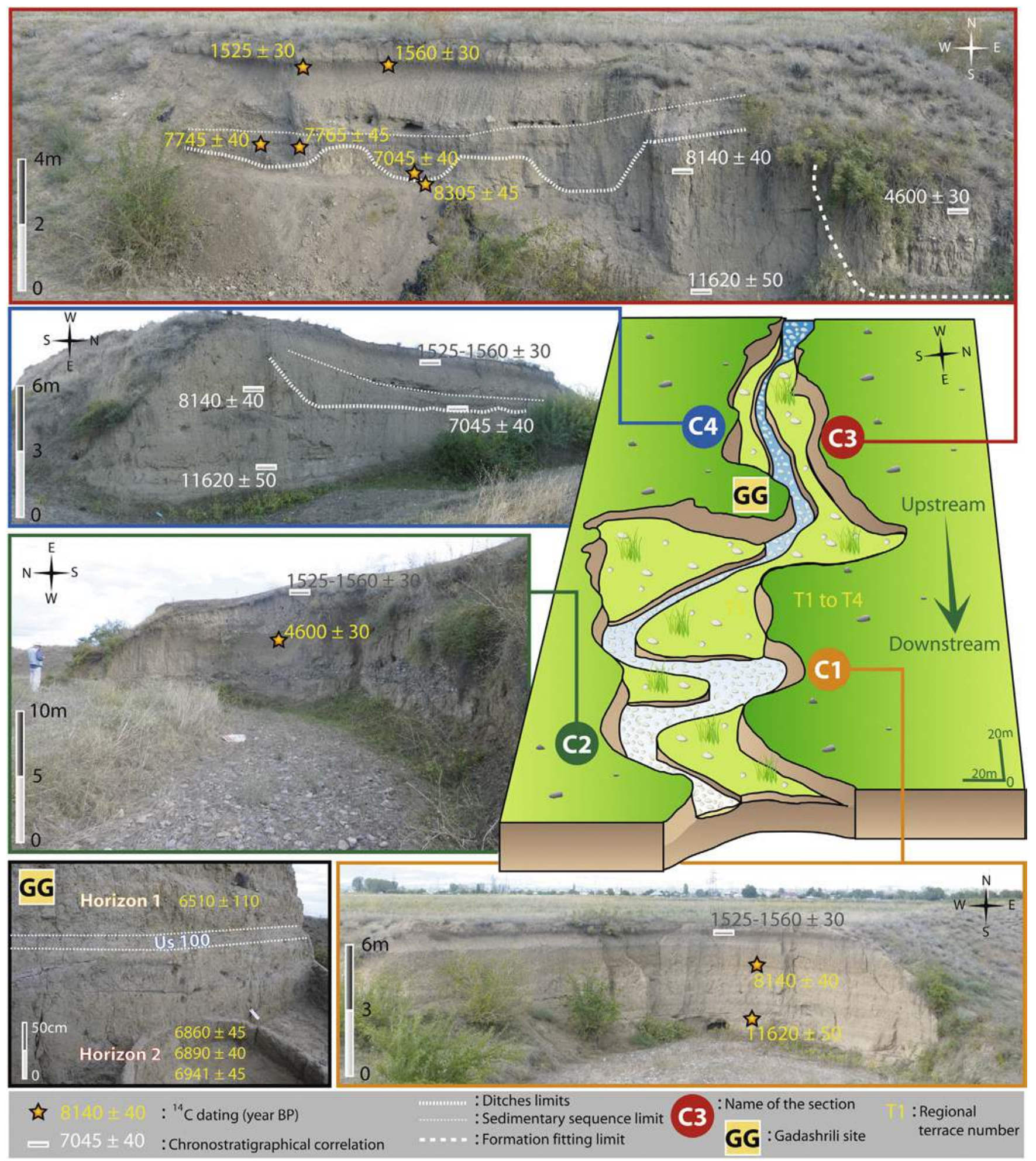

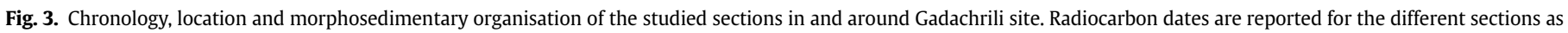
well as for Horizon 1 and Horizon 2 of the excavation framing the US 100 unit.

to avoid erosion of the raft. In the small anthropogenic channels of Gadachrili (Fig. 11), the "Hjulström values" indicate flows between $>10$ and $>100 \mathrm{~cm} \mathrm{~s}^{-1}$ for initial filling and $>0.1$ to $>1 \mathrm{~cm} \mathrm{~s}^{-1}$ for the last flow of the structure. Integrating the section dimension of the Neolithic canals, these last estimates are confirmed by hydraulic calculations (Table S1 and Fig. S2) on a parametric section giving us values close to around $16.5 \mathrm{~cm} \mathrm{~s}^{-1}$ for the average flow velocities during their conventional use. These data are incomplete and with future work (track tracing, slope measurements, reconstructions of precise channel morphologies), more precise relative velocities should be given. However, these preliminary observations indicate that the flow velocities of this type of hydraulic structure were 


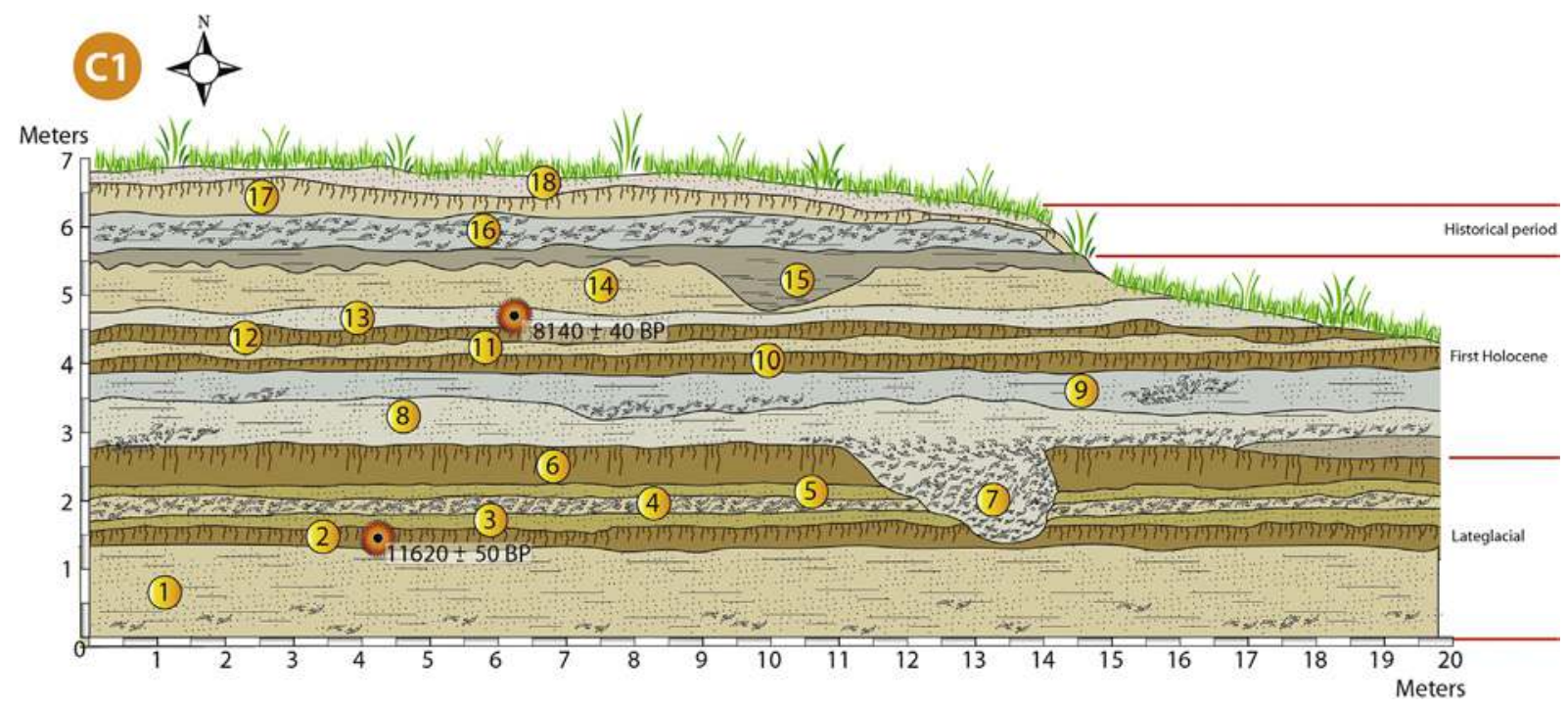

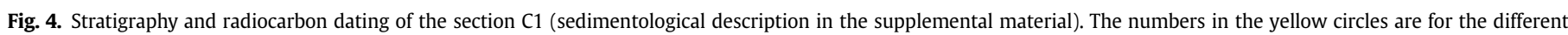
stratigraphic levels. (For interpretation of the references to colour in this figure legend, the reader is referred to the Web version of this article.)

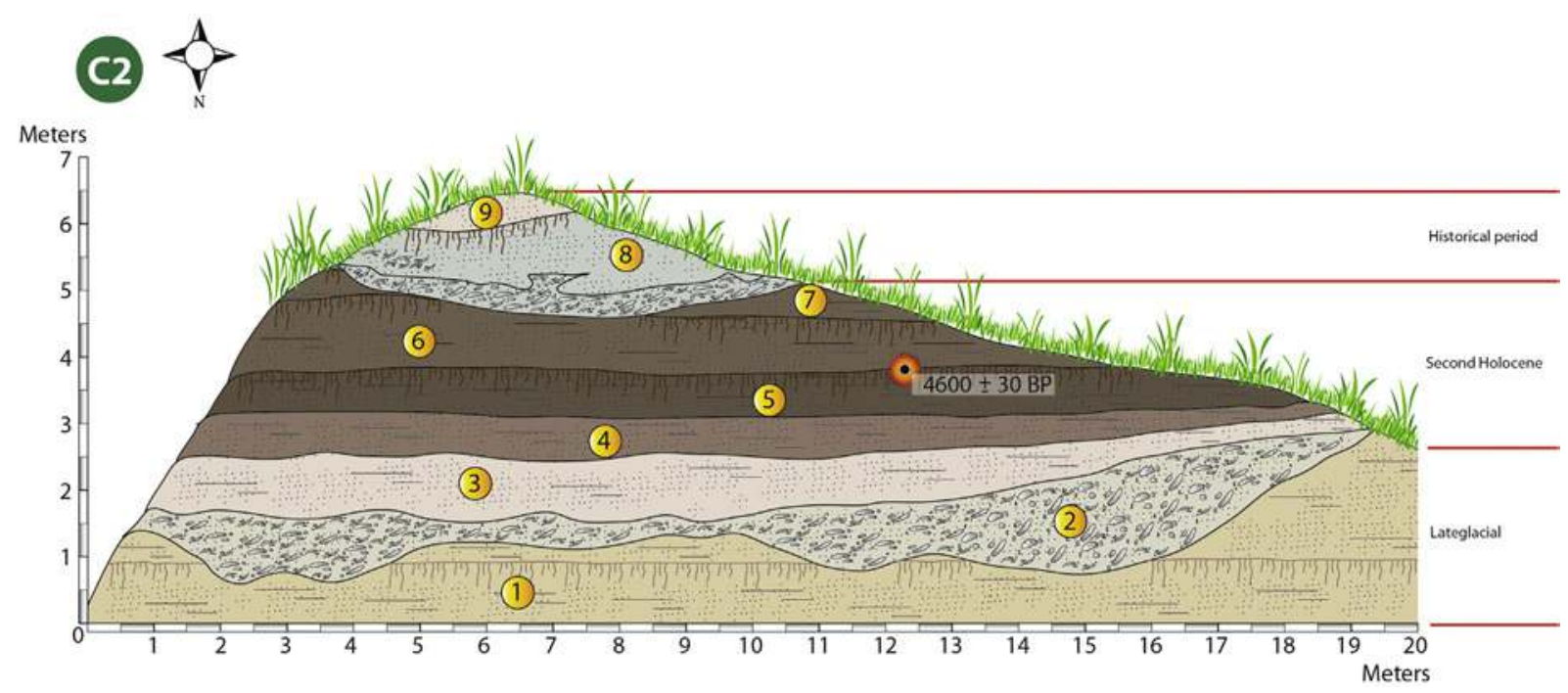

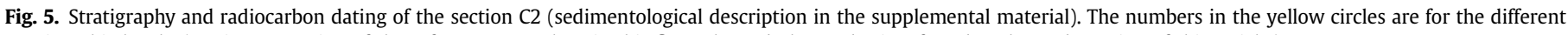
stratigraphic levels. (For interpretation of the references to colour in this figure legend, the reader is referred to the Web version of this article.)

small but consistent with the current modest average flow observed for the Shulaveri river of $0.44 \mathrm{~m}^{3} \mathrm{~s}^{-1}$. In addition, the simultaneous water filling of the three channels would provide an average relative velocity of $0.49 \mathrm{~m}^{3} \mathrm{~s}^{-1}$ consistent with our data. As we have pointed out earlier, only part of their history is recorded in stratigraphy. The different characteristics depicted in the geometry, the feasibility, and viability of these channels, as well as the division of the main canal into three separate channels over a few meters in a soft lithological context and under a torrential regime, excludes a natural origin in their initial development.

At least two major palaeofloods are recorded in the stratigraphy of the Shulaveri river deposits surrounding the site of Gadachrili (Figs. 3-8, Figs. 11 and 12). This river of second order (Strahler, 1957) ephemeral stream has a high reactivity to hydrometeorological events (circular morphometry of the upstream basin, and numerous series of lateral drains and gullies from upstream to downstream) with water supplying the anthropic channels. Modest but repeated during the Lateglacial period, the floods are much more marked in the Holocene (Figs. 4-8, Figs. 11 and 12) by their intensity and seem to acquire a more regional character (Ollivier et al., 2015, 2016). The stratigraphic flood sequences observed also underline the high long-term mobility and palaeohydrological variability of the Shulaveri river course (Fig. 13), especially in the sector corresponding to the alluvial fan (which flow direction, sedimentary supply, and morphology are under the control of climate changes, tectonic, and base level variations). Looking at the archaeological sequences from the Gadachrili site excavation (Hamon et al., 2016), flood deposits are visible in stratigraphic unit US 100 (silty-sandy olive green level with fine bedding and traces of oxidised rootlets, Fig. 3 and photo S1), the archaeologically sterile stratigraphic unit; a transition between anthropogenic horizons 1 and 2 respectively dated at $6941 \pm 50 \mathrm{BP}(7768 \mathrm{cal}$. BP/5856 cal. BC) and $6510 \pm 110 \mathrm{BP}(7418 \mathrm{cal}$. BP/5463 cal. BC). The US 100 stratigraphic unit is also stratigraphically, faciologically, chronologically 


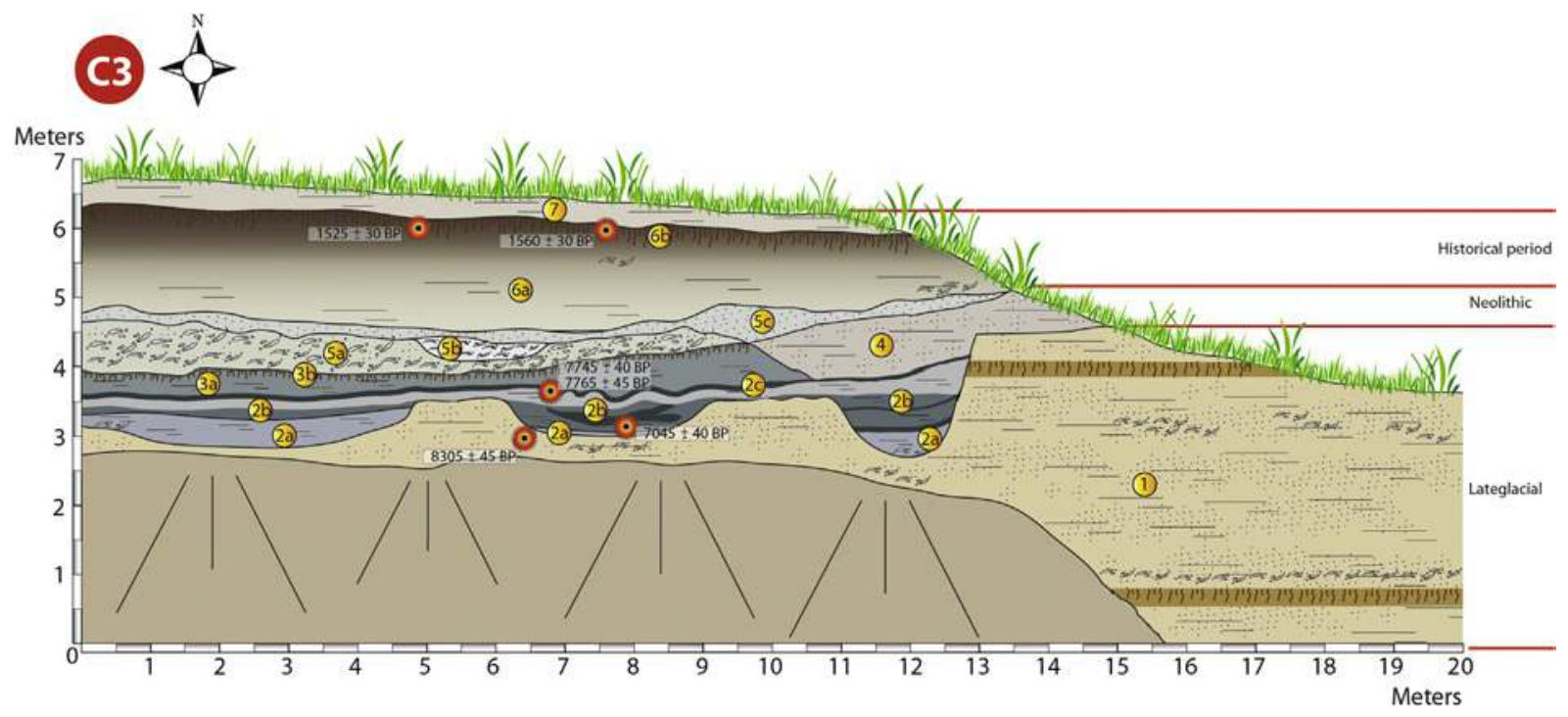

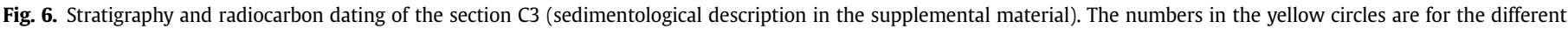
stratigraphic levels. (For interpretation of the references to colour in this figure legend, the reader is referred to the Web version of this article.)

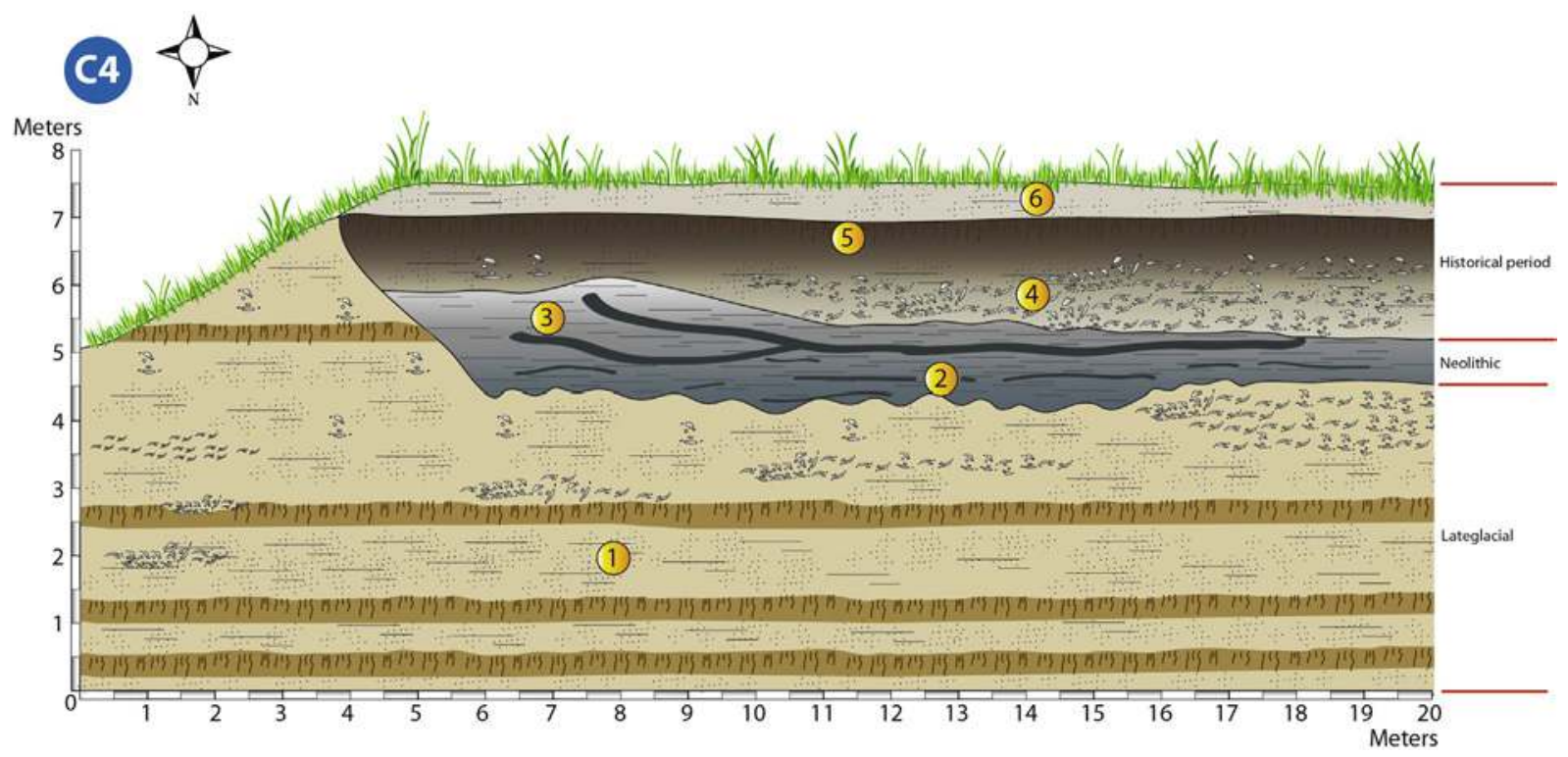

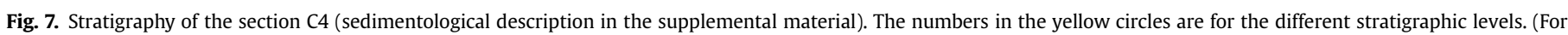
interpretation of the references to colour in this figure legend, the reader is referred to the Web version of this article.)

$\left({ }^{14} \mathrm{C}\right)$ and geometrically well correlated with the levels 3a and 4 of the hydraulic structures studied in sections C3 and C4 (Figs. 11 and 12 and Fig. S1), which indicates the partial destruction of the hydraulic structures and their progressive abandonment. As noticed in Hamon et al. (2016), the archaeological stratigraphy shows two horizons with different types of organisation of the settlement area. Evidence from the deepest occupation levels also suggests different building techniques between the two horizons. It is difficult to ensure that the architectonic changes are clearly the results or have been influenced by these flood episodes. But the overlap of the site between the two horizons by the US 100 stratigraphic unit (Fig. 3) with distal alluvial characteristics (probably decantation and development of a temporary quasi-wetland) clearly indicates that hydraulic structures of sections C4 and C3 have brought the floods to the site of occupation by diverting the waters of the Shulaveri river. This dynamic has persisted over time, leading to the abandonment and destruction of hydraulic structures (Figs. 11 and 12). The impact of hydraulic equipment works (notably canals) on the spread of floods and the damage they cause is well known today. This is the case even during violent but not exceptional hydrometeorological events (Arnaud-Fassetta et al., 2002). On the Neolithic site of Gadachrili and its surroundings, the potential morphosedimentary and archaeological record of this type of phenomenon can surprisingly be found.

\subsection{Components of the Shulaveri river fan}

The analysis of satellite photos coupled with field investigations and laboratory analysis allowed us to trace all the different courses and to specify the development of the alluvial fan of the Shulaveri 


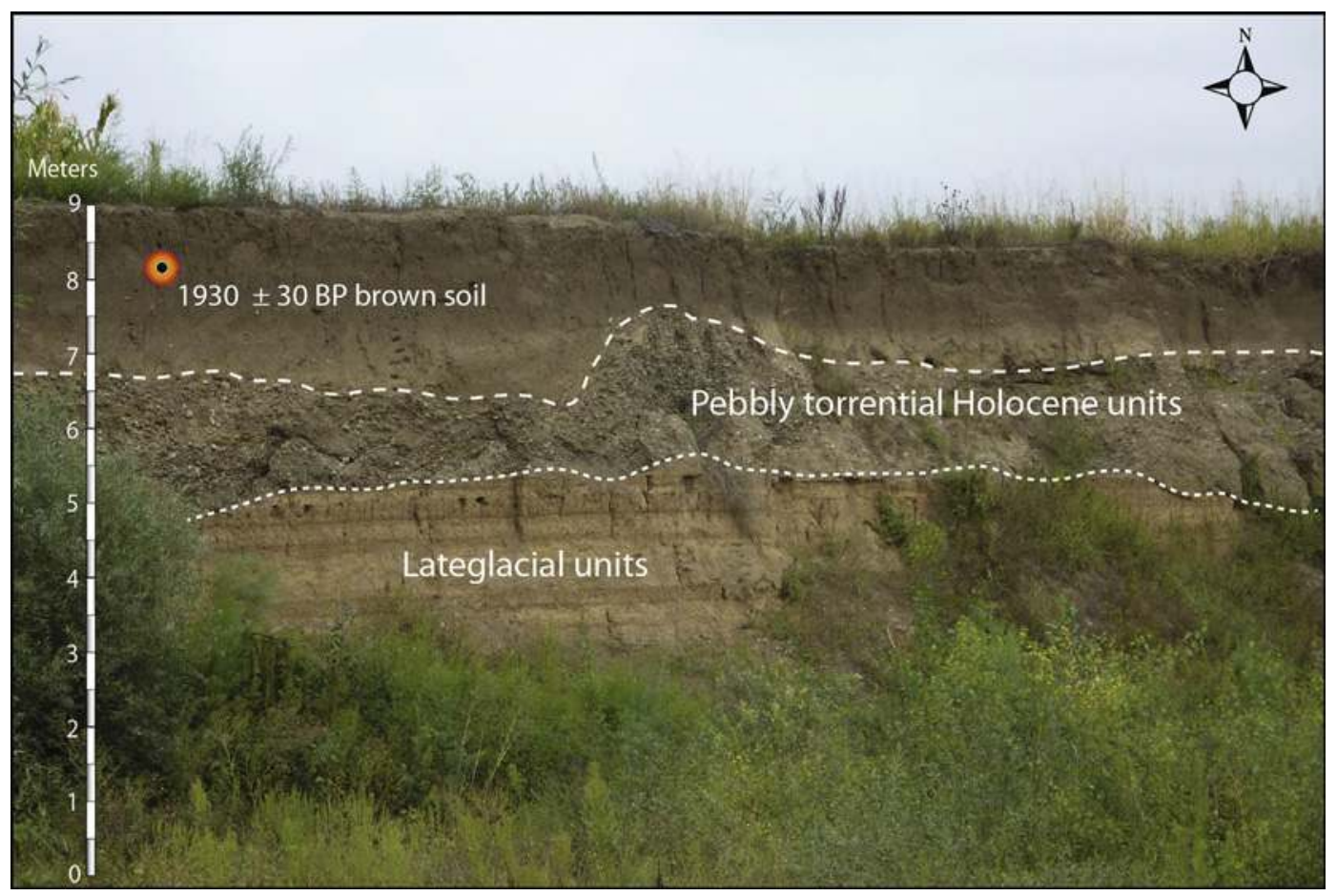

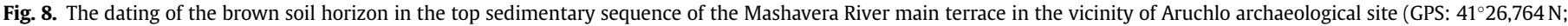

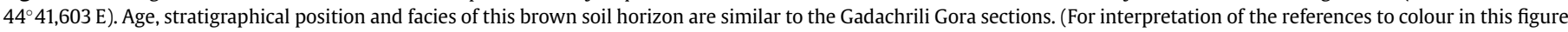
legend, the reader is referred to the Web version of this article.)

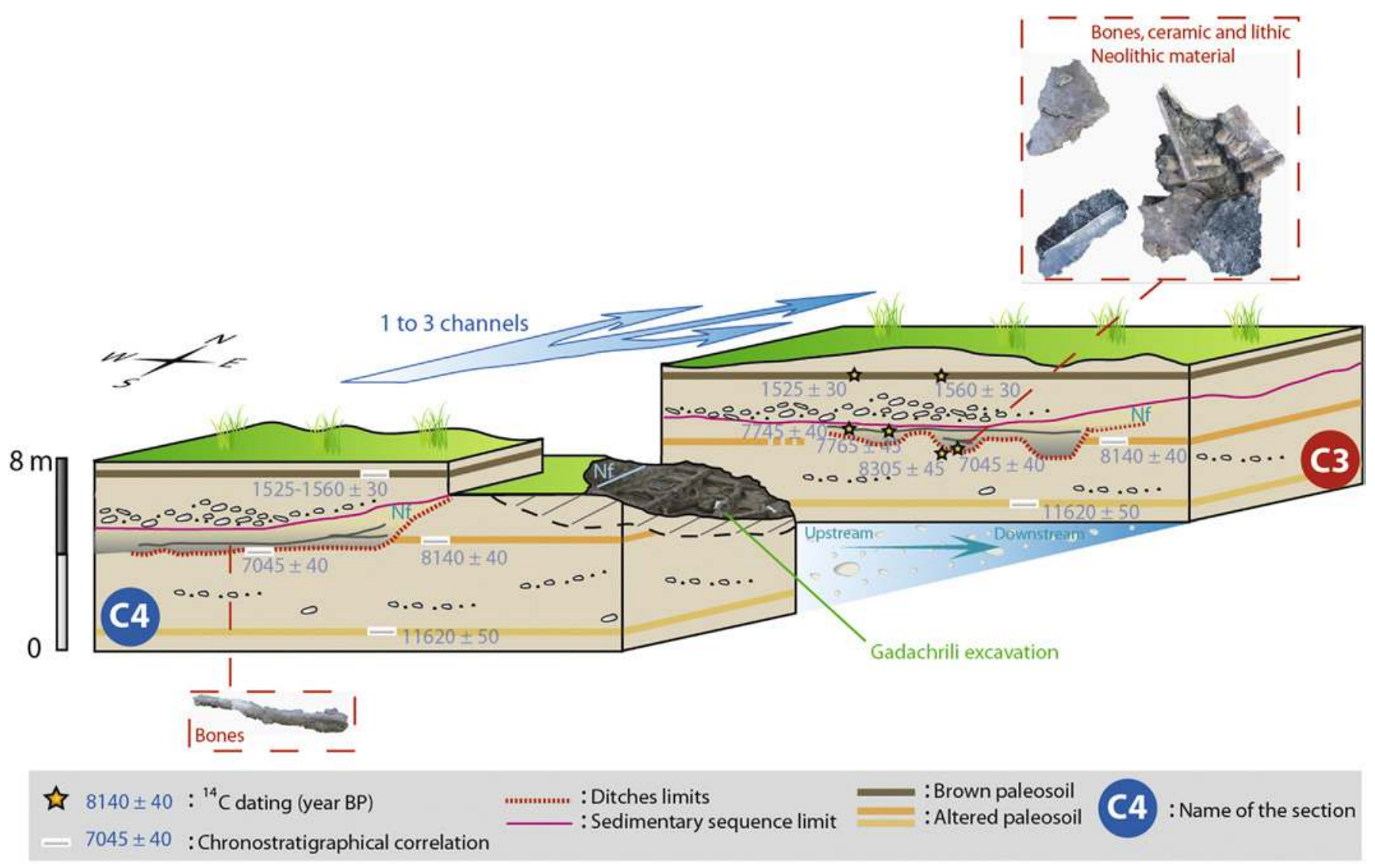

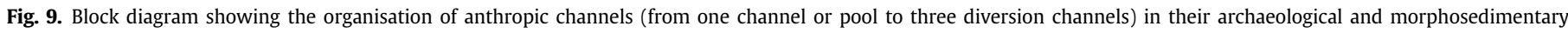
context. 


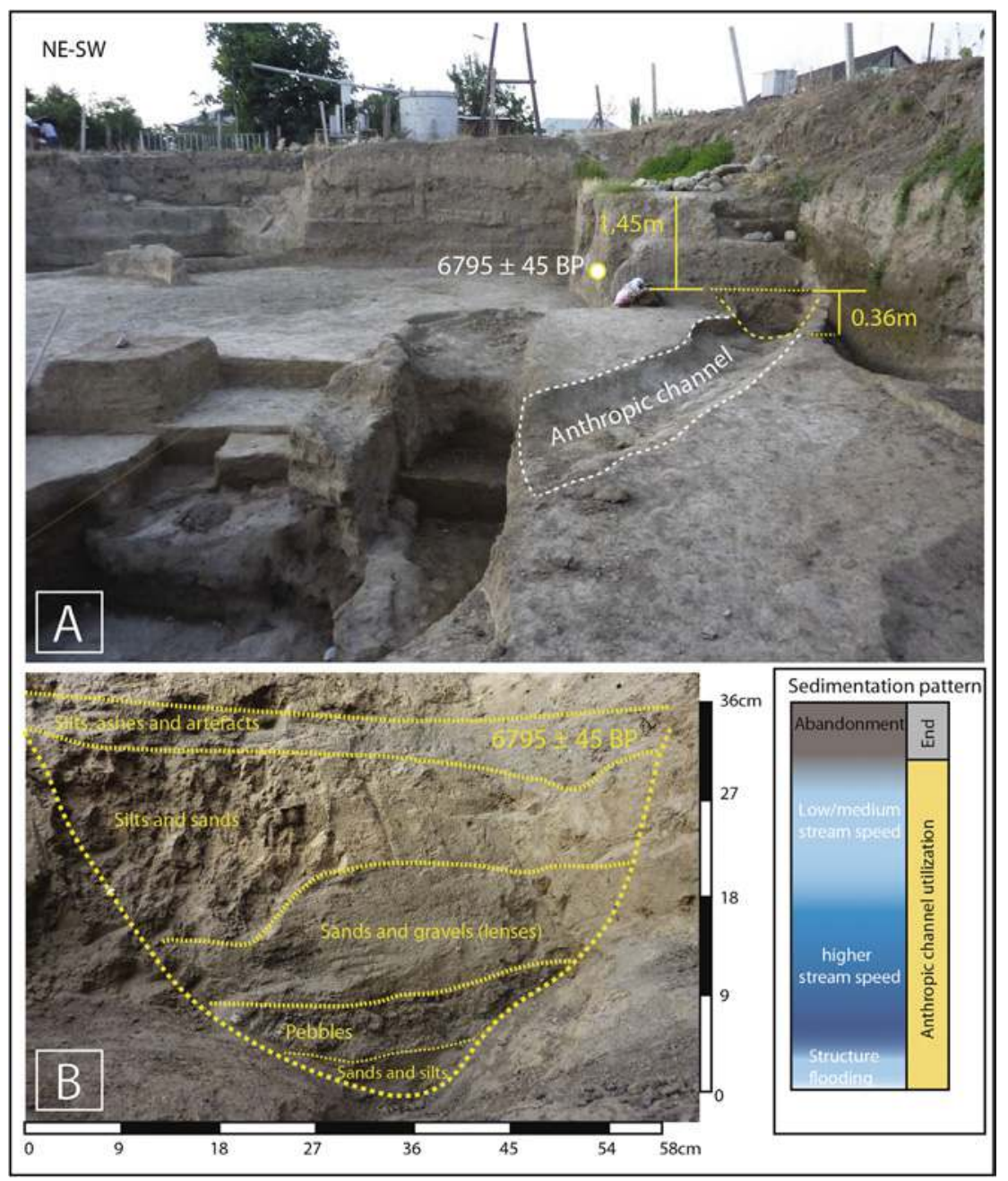

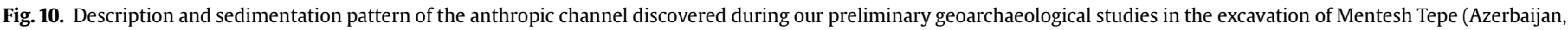
GPS: $40^{\circ} 56,514 \mathrm{~N} ; 45^{\circ} 49,986 \mathrm{E}$ ) directed by B. Lyonnet (Lyonnet et al., 2012, 2016, 2017).

river since the Lateglacial (Fig. 13).

The evolution of the alluvial fan of the Shulaveri river (Fig. 13) appears to have followed a process of global lobe migration to the east. Thus, at least seven stages marked by as many talwegs could be defined for the Shulaveri river in its eastward migration.

The physiography of the local hydrographic network is clearly influenced by tectonics (Suchodoletz et al., 2016). Nevertheless, a distal impact of the variations in the relative level of the Caspian Sea on the morphosedimentary dynamics of the regional rivers is not entirely excluded (Ollivier and Fontugne, 2012; Ollivier et al., 2015, 2016; Ollivier et al., 2015). Ongoing work attempts to precisely define the upstream spatialisation of this phenomenon for the Lesser Caucasus hydrosystems, connected in the first or second order to the Caspian Sea basin (Ollivier, in press).

\subsection{Palaeobotanic and isotopic analyses on the seeds to test the possibility of irrigation practices}

Several crops were identified in the samples coming from the excavations conducted in 2012 and 2013. Among the cereals, emmer (Triticum turgidum subsp. dicoccum) dominating during horizon 2, barley (Hordeum vulgare), a major crop during horizon 1, and, in lower numbers, naked wheat (Triticum aestivum/durum) were found. Among the pulses, lentil (Lens culinaris) and a pea- vetches type (Pisum-Vicia) were recorded. Several arable plants, probably arable weeds, were also recognised (Adonis sp., Aegilops sp., Scleranthus annuus etc.). The study of charcoal fragments, coming probably from the use of wood as fuel, shows no clear change in the source area for wood collection. A riparian forest, with poplar and/or willow (Populus-Salix) or ash tree (Fraxinus sp.), dominates during the two horizons of the occupation, whereas other trees seem more characteristic of more open woodlands such as for example buckthorn (Rhamnus sp.) or maple tree (Acer sp.). This reconstruction of riparian, but also open vegetation cover highlights the occurrence of cultivable and irrigable areas.

Twenty-nine seed samples analysed for carbon stable isotope ratios show a data range from -25.0 to $-22.7 \%$ o $(\Delta=2.3 \%, \mathrm{n}=29$; Table 2). The $\delta^{13} \mathrm{C}$ of the two stratigraphic zones (Fig. 14) varies within the same range (from -25.0 to $-23.1 \%$, med $=-24.0 \%$, $\mathrm{n}=19$, for $\mathrm{H} 2$ and from -24.4 to $-22.7 \%$, med $=-23.7 \%$, $\mathrm{n}=10$, for $\mathrm{H} 1$; Fig. 14). The carbon isotopic ratios of barley samples are lower for the stratigraphic zone $\mathrm{H} 2$ compared to the oldest zone $\mathrm{H} 1$ (Fig. 14). However, this result is not statistically significant (nonparametric tests performed with Statistica ${ }^{\circledR} 7.1$; Mann-Whitney $U$ test: $\mathrm{p}=0.56$; Median test: $\mathrm{p}=0.08$ ).

Fig. 14 also presents a comparison between the $\delta^{13} \mathrm{C}$ levels of six charred seeds of Early Neolithic barley from Gadachrili and Early Bronze Age wheats from Chobareti sites also located in Georgia 

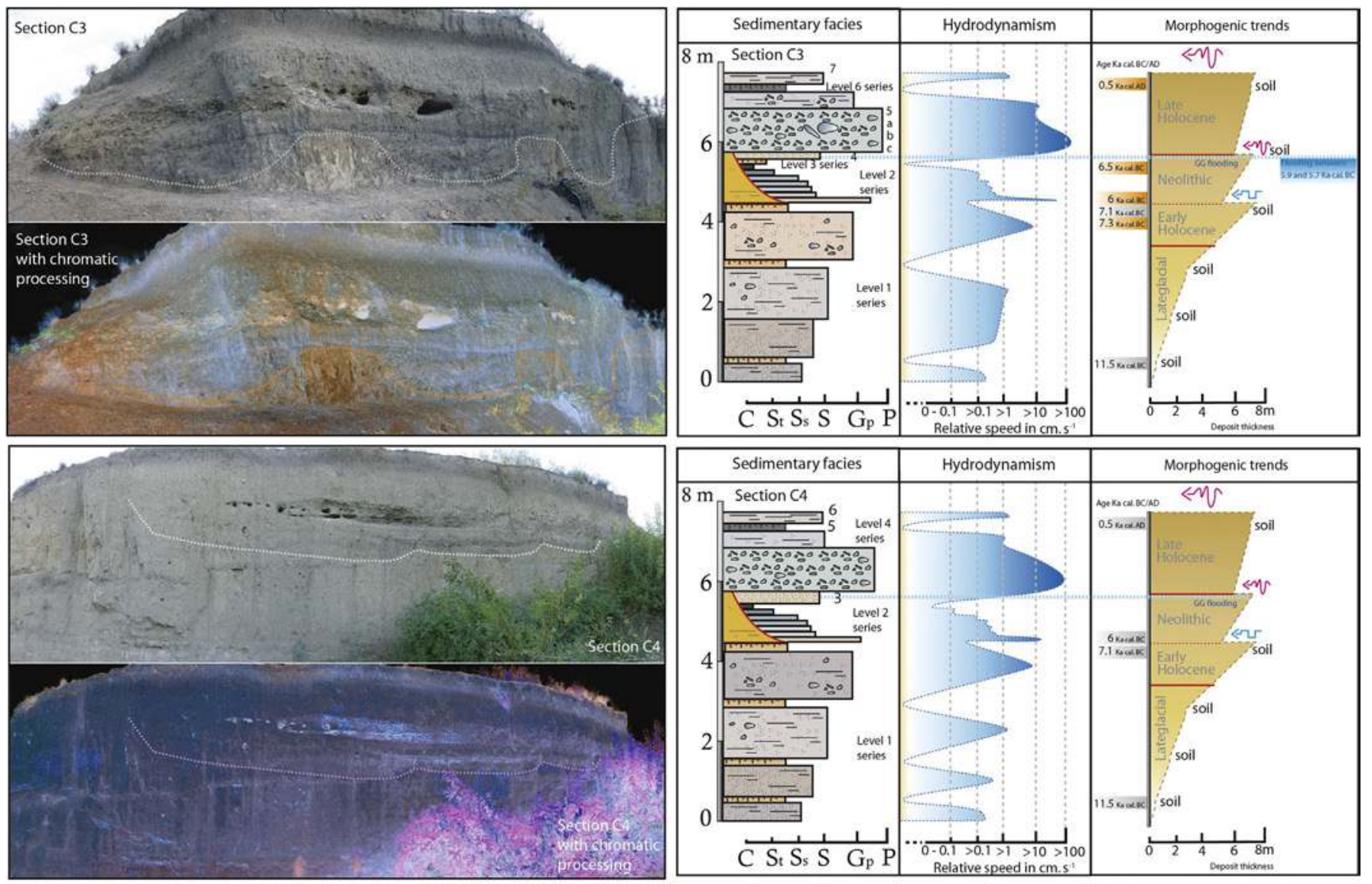

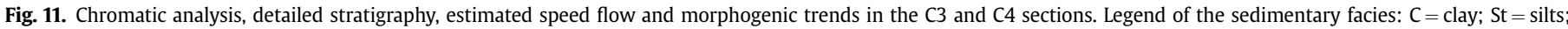

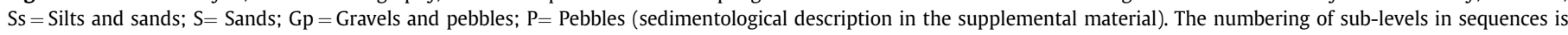
simplified ( 1 series, 6 series, etc.).

(Messager et al., 2015). This comparison of sites from different chronologies and slightly different contexts are made: 1 ) to attempt to discriminate irrigation practices; 2 ) to check the possible irrigation practices persistence in the long duration where variations in climatic humidity succeed each other between $5900 \mathrm{cal}$. BC (regionally presumed wetter) and 3000 cal. BC (regionally presumed drier); 3 ) and to test the palaeoclimatic results regionally obtained.

In Gadachrili, the isotopic values recorded are low and statistically homogeneous. In Chobareti (Messager et al., 2015), the isotopic analyses are from different species and at a higher altitude compared to Gadachrili, but with weak deviations among the values, around $1.3-1.4 \%$. The Early Bronze age samples show much higher $\delta^{13} \mathrm{C}$ values compared to early Neolithic ones; this result is statistically significant (Mann-Whitney $U$ test: $\mathrm{p}<0.01$ ). The Chobareti isotopic values seem to indicate a generally drier environment.

\section{Discussion}

\subsection{The geomorphic events kinematics}

The pattern of environmental changes proposed was compared to the isotopic data from GRIP (Andersen et al., 2006), INTIMATE (Rasmussen et al., 2014), Sofular Cave (Fleitmann et al., 2009), Central Asia (Chen et al., 2008), and the Black Sea (Shumilovskikh et al., 2012) to obtain a representative analysis based on climatic records (Ollivier et al., 2015, 2016). Local climatic and bioclimatic references are also of importance and were included in the morphodynamic reconstruction using the surrounding pollen records of Shamb (Ollivier and Fontugne, 2012), Paravani (Messager et al., 2013), Zarishat (Joannin et al., 2014), and Nariani (Messager et al., 2017) in Armenia and Georgia. Regional (Mosar et al., 2010) to local (Suchodoletz et al., 2016) tectonic knowledge were also included in order to determine the long-trend evolution of the hydrosystem.

Considering the numerous parameters involved (climatic, tectonic, and potentially base level changes), channel 1 (Fig. 13), incised in the alluvial Postglacial formations, could be a feedback from the hydrosystem to the Mangyshlak regression (end of the Lateglacial/early Holocene). Channels 2, 3, and 4 (Fig. 13) could be considered as an avulsion from the early Holocene highstand (Ollivier et al., 2016). Channels 5 and 6 (Fig. 13) could be the riverbed contemporary to the Neolithic occupations, and talweg 7 (Fig. 13) the one driven by the incision of the Khrami river after 603525 cal. AD (tectonically driven? Suchodoletz et al., 2016). These different rhythms of sedimentation could be comparable to those linked to climate changes and variations in the base level highlighted further downstream (Ollivier et al., 2015, 2016). However, they mainly show that the Kura river and its tributaries form a complex system.

Considering all the data analysed, the following human occupation and postglacial landscape evolution kinematics can be proposed (Fig. 15): 


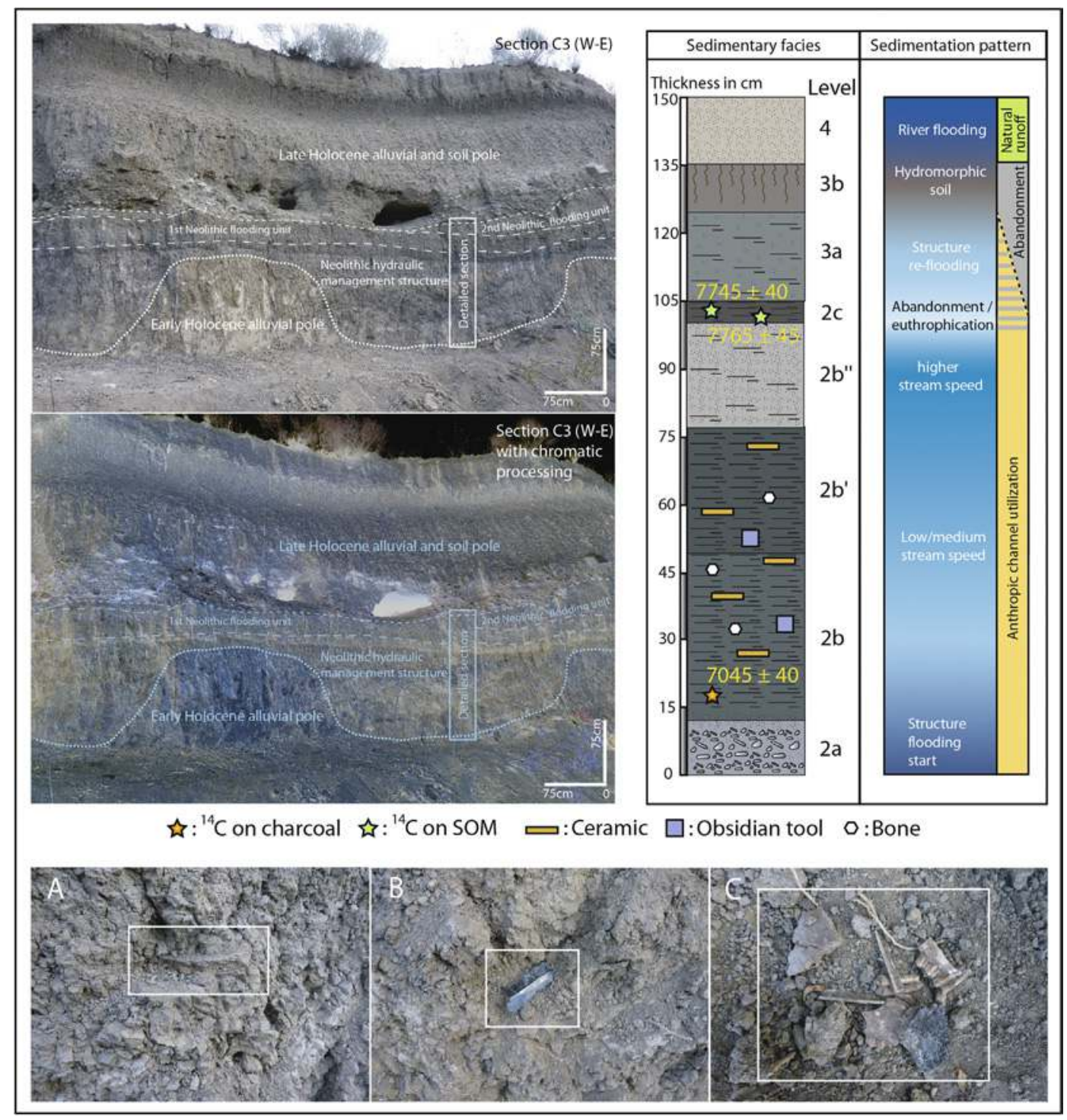

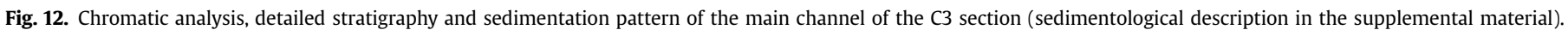

A) A development of the Shulaveri river alluvial fan before $11,620 \pm 50 \mathrm{BP}(13,450$ cal BP, $11,615 \mathrm{BC})$ in a poorly drained system with multiple weakly active channels and lobes. This type of fluvial geomorphology occurred during the Greenland Interstadial 1C1 (Rasmussen et al., 2014) that is known to be regionally dry and relatively cold with an arid and steppe environment (Wright et al., 2003; Messager et al., 2013; Leroy et al., 2013a, b). It is followed until the Early Holocene by higher sedimentation rates and the growth of torrentiality in a more temperate-humid climate (Ollivier et al., 2011, 2015, 2016; Messager et al., 2013; Joannin et al., 2014).

B) An incision and concentration of the Shulaveri riverbed in a steppe environment (Joannin et al., 2014; Messager et al., 2017), around 9000- $8200 \mathrm{cal}$. BP (around 7000-6200 cal. $\mathrm{BC})$. The end of this period is globally known to be a cold and dry event accompanying the expansion of the EurasianSiberian High (Renssen et al., 2002; Vellinga and Wood, 2002, Morrill and Jacobsen, 2005).

C) Increased and more regular river flow in the course of a more humid climatic phase recorded around 8200-7500 cal. BP/
6200-5500 cal. BC (Joannin et al., 2014) registering and/or succeeding to the $8200 \mathrm{cal}$. BP event (Thomas et al., 2007). In this favourable hydroclimatic context, the Gadachrili site and its hydraulic management structures are developing. A few centuries earlier, the vegetation history started to shift from open to forested vegetation (Joannin et al., 2014; Leroy et al., 2013b; Messager et al., 2017).

D) Development of one or several floods of the Shulaveri river around 7900-7700 cal. BP (5900-5700 cal. BC). Although the river was far away, the waters flow through the canals and flood the site of Gadachrili. The sedimentary signal is recorded by the stratigraphic unit US 100 (Fig. 3, Fig. S1, and photo S1) showing a facies (sterile silt), probably marking the spreading of the floodplain in the archaeological structures (low to medium energy flows and colonisation by herbaceous vegetation in moist environments).

E) After $7700 \mathrm{cal}$. BP ( $5700 \mathrm{cal}$. BC), end of the extension of the flood episodes on the site, development of Horizon 1 around 7400 cal. BP (ca 5600 cal. BC). Possible abandonment of the channels. No evidence for visible hydraulic structures or for their reuse are registered in the sedimentary sequences. 


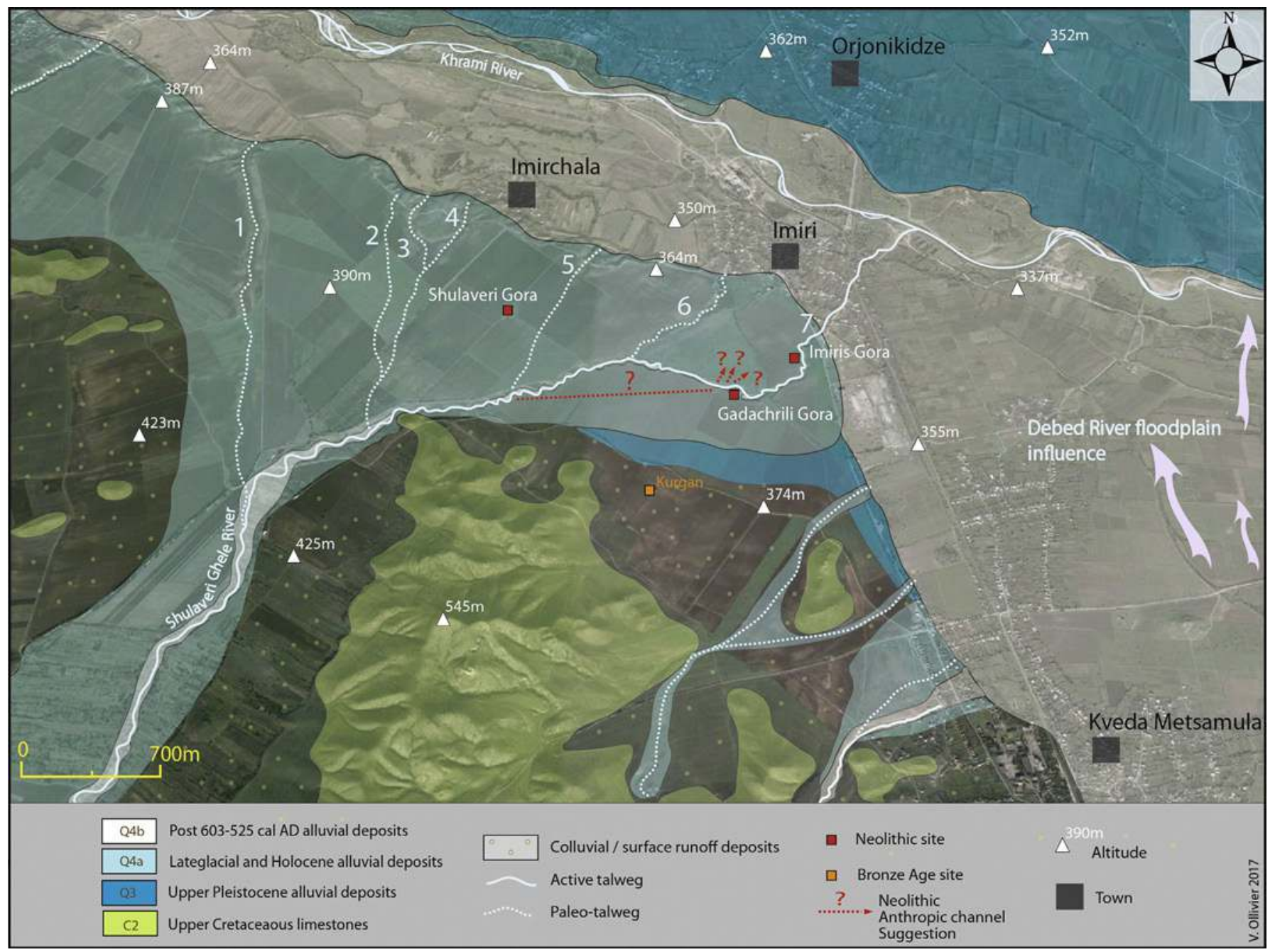

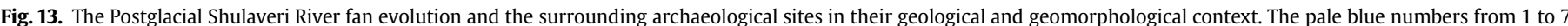

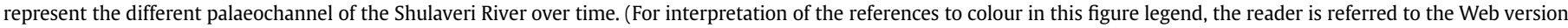
of this article.)

F) Around 5500-5300 cal. BP (3500-3300 cal. BC), a local reorganisation of the riverbed with a probable linear incision of the Shulaveri river and an eastward shift of its course. An increase in torrentiality and a development of soils on the riverbanks occurs. Regional climatic signals record drier phases at approximately 5300-4900 cal. BP (Joannin et al., 2014).

G) At $1410-1466$ cal. BP (ca 500 cal. AD), the Shulaveri river seems to change its course. Previously, the climate underwent a regionally drier phase around 2200-1500 cal. BP (Joannin et al., 2014). A thick brown soil horizon is developed probably due to a change in the river course. The lateral connectivity is broken resulting in a temporary disconnection of the river from its usual floodplain and in an interruption of aggradation. Later, the floodplain is reoccupied and alluvial sandy deposits cover the brown pedogenic horizon.

H) Afterwards a lowering of the base level defined by the Khrami river (tectonically and or retroactively driven?) generates another eastward shift in the course of the Shulaveri. This is part of a linear incision dynamic that dissects the archaeological site of Gadachrili.

\subsection{The Postglacial regional morphoclimatic components}

For the Lateglacial, the facies and the morphosedimentary organisation observed in the alluvial deposits of Gadachrili echoes those analysed in various similar formations in the Lesser Caucasus (Ollivier et al., 2015, 2016; Montoya et al., 2013). The sedimentary bodies are representative of a weak longitudinal sedimentary transfer under the climatic characteristics of the Greenland Interstadial 1 c1 (GI-1 c1, Rasmussen et al., 2014). The competency of river sediment transport decreases and the dominant facies are silty. Alluvisoils developments are frequent in relation to spasmodic, irregular, and low-energy flows but with a slight torrential component. In some mountainous areas close to Gadachrili, pollen assemblages indicate open vegetation with occasional trees developing in valley bottoms (Montoya et al., 2013). These conditions resulted from a regionally known cold and dry climate (Montoya et al., 2013; Messager et al., 2013). The first part of the Holocene shows an increase in upstream-downstream hydrological energy and sediment transfer. As regionally seen (Ollivier et al., 2015), sandy and gravel-pebble facies are more frequent and feed the end of the alluvial fan, a sector morphologically in loss of transit energy. A more humid and warmer climate with contrasting or differently distributed rainfall regimes (Joannin et al., 2014) leads to 
Table 2

Carbon isotopic ratios from archaeological seeds of Horizon 1 and Horizon 2 in Gadachrili.

\begin{tabular}{lllll}
\hline Sample & N seed/sample & Horizon & US & $\delta^{13} \mathrm{C}(\%)$ \\
\hline GGBOT113 & 1 & 2 & 114 & -24.0 \\
GGBOT052 & 5.5 & 2 & 119 & -23.7 \\
GGBOT053 & 10 & 2 & 120 & -24.3 \\
GGBOT102 & 3 & 2 & 121 & -23.1 \\
GGBOT110 & 3 & 2 & 122 & -24.9 \\
GGBOT023 & 10 & 2 & 123 & -24.3 \\
GGBOT066 & 2 & 2 & 126 & -23.5 \\
GGBOT095 & 0.5 & 2 & 131 & -24.6 \\
GGBOT078 & 11 & 2 & 142 & -23.6 \\
GGBOT020 & 2 & 2 & 143 & -23.9 \\
GGBOT077 & 8 & 2 & 147 & -24.0 \\
GGBOT042 & 1 & 2 & 155 & -25.0 \\
GGBOT099 & 9 & 2 & 164 & -24.3 \\
GGBOT109 & 10 & 2 & 165 & -23.3 \\
GGBOT098 & 2 & 2 & 204 & -25.0 \\
GGBOT121 & 5 & 2 & 213 & -23.8 \\
GGBOT049 & 10 & 2 & 216 & -24.9 \\
GGBOT044 & 10 & 2 & 220 & -24.3 \\
GGBOT097 & 10 & 2 & 227 & -24.0 \\
GGBOT039 & 6 & 1 & 2006 & -24.4 \\
GGBOT009 & 10 & 1 & 2013 & -23.5 \\
GGBOT002 & 6 & 1 & 2017 & -23.7 \\
GGBOT038 & 10 & 1 & 2024 & -24.0 \\
GGBOT008 & 6 & 1 & 2025 & -22.7 \\
GGBOT037 & 8 & 1 & 2037 & -23.5 \\
GGBOT063 & 10 & 1 & 2039 & -23.8 \\
GGBOT071 & 2 & 1 & 2040 & -23.2 \\
GGBOT090 & 4 & 2040 & -24.2 \\
GGBOT065 & 10 & 23.8 \\
\hline
\end{tabular}

the development of new torrential activity. The shift following the 8.2 ka event is well recorded by a marked increase in springsummer rainfall and the forest development in the Lesser Caucasus and many regional data (Fleitmann et al., 2009, Chen et al., 2008, Shumilovskikh et al., 2012, Ollivier and Fontugne, 2012, Messager et al., 2013, Joannin et al., 2014, Messager et al., 2017, Fig. 16). It is also potentially linked to the Black Sea influence on the regional precipitation regimes and or its potential interactions with the monsoon mechanism (Messager et al., 2017). The second Holocene period records a fall in the sediment transport capacity with the predominance of silt and sand facies as well as the development of thick brown soils. This could be associated with a drier climate observed in the palaeoclimatic models (Davis et al., 2003; Wanner et al., 2008). In terms of local hydrogeomorphic dynamics of the Shulaveri river, some results, mainly focused on the archaeological site of Gadachrili, are broadly in line with more recent studies on the subject (Suchodoletz and Faust, 2017). Further comparisons with previous investigations, however, seem necessary.

\subsection{Neolithic land use, water management, and flooding}

The Gadachrili canals are probably dug to divert the waters of the Shulaveri river in order to bring this resource closer to the village. The channel characteristics shown in the section C4 (Fig. 9) would suggest a storage pond (Whitehead et al., 2008) or a large artificial arm that drives or collects some of the waters of the Shulaveri river to distribute them in the other canals in its extension as a water supply system (section C3, Fig. 9). This may be a quasi-perennial water supply without being exposed to the frequent (annual to decennial) and direct torrential floods of the Shulaveri river.

The $8.2 \mathrm{ka}$ BP climatic event is frequently connected with a restructuring of prehistoric communities and the expansion of farming in the Levant, northern Mesopotamia, northeastern
Mediterranean region (e.g. Weiss and Bradley, 2001; Staubwasser and Weiss, 2006; Weninger et al., 2006; Turney and Brown, 2007; Berger and Guilaine, 2008; Pross et al., 2009). Frequently, Neolithic populations settled in areas where they could use the natural irrigation of river and lake floodplain (Van Andel and Runnels, 1995). In Gadachrili, canal construction could be motivated by the 8.2 ka climate change resulting in particular in a regional increase in humidity (Fig. 16 and Joannin et al., 2014, Messager et al., 2013, Messager et al., 2017). Floods spread to human occupations located on the distal part of the alluvial plain and caused by a poorly managed hydraulic system. The evidence of these hazards are rare and very precious in archaeology. Some stratigraphic evidence for uncontrolled flooding in prehistoric canals have already been studied in Arizona (Huckleberry, 1999) and in Peru (Huckleberry et al., 2012). But in Gadachrili, probably the first if not the oldest evidenced prehistoric "civil engineering disaster" occurred. Sediment source and modes of deposition within the channels vary according to the geomorphological setting and/or the climatic components. Channel fill deposits are the testimony of canal flow regulation, of the natural flooding episodes, or of the post abandonment of the structure including flooding and slopewash from the adjacent berns. They can record the impacts of natural hazards on prehistoric societies as we have assumed for Gadachrili. But it is difficult to date the construction and early use of these kind of water management structures. In addition, the hydraulic calculations show that the Neolithic hydraulic structures of Gadachrili were to be marked by strong sedimentation (due to a low flow velocity) and frequent cleaning in order to guarantee a minimal flow. This indicates that much information about the history of these channels is missing. In the case of Gadachrili, the proximity of the occupation was a determinant factor to correlate both kinds of structures and activities. However, sedimentostratigraphic evidence remains to be found concerning the relations between agriculture and the need for such hydraulic structures.

\subsection{Irrigation and the Lesser Caucasus}

Surface irrigation (or gravity irrigation) uses gravity. The water is conveyed by means of channels and ditches of decreasing size. This last characteristic would fit well with what is observed in the studied sections C3 and C4. The watering itself is carried out by runoff, by submersion or by infiltration in the subsoil close to the crops. Plots with a uniform slope and low amplitude, as in the case of the alluvial fan of the Shulaveri river, lend themselves well to irrigation because they reduce the difficult earthworks. The Gadachrili's diversion system certainly consists in improving the water-efficient pattern fragilely based on the regional precipitation rates and floodplain supply. It was supported by the increase in climatic humidity following the 8200 cal. BP event in the region (Fig. 16). During this wetter period, watercourses should provide a more perennial and more regular flow, partially erasing the current disadvantages inherent in the drying-up of the Shulaveri river-type torrential systems during the summer. This creates an original environmental context that makes difficult to literally use the term "irrigation", usually more dedicated to areas (with arid or semi-arid climate) where the natural rainfall and soil hygrometry are insufficient to support crops for rainfed agriculture.

The low and statistically homogeneous isotopic values recorded could underline the humidity of the climate around and after the $8.2 \mathrm{ka}$ event. Irrigation practice is not ruled out, but the isotopic signals seem homogenised by this more humid environment. During the summer period, eventual irrigation would be insufficient to impact the $\delta^{13} \mathrm{C}$ values, as grain crops mature during this season and do not require water supply (interruption of irrigation 

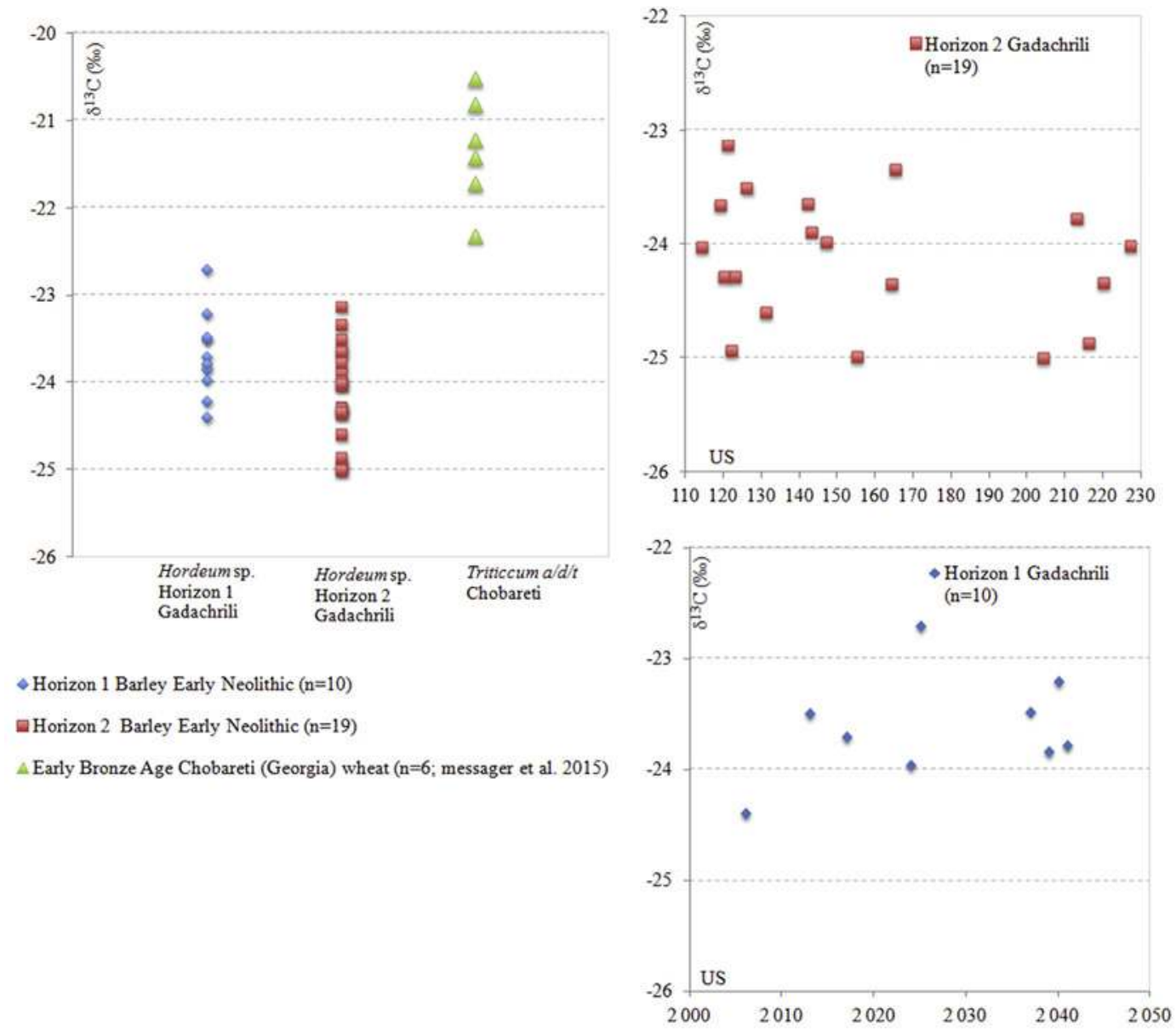

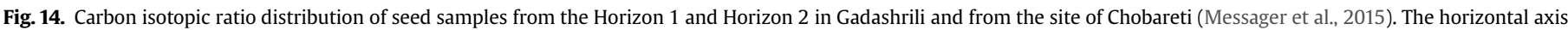
is for the different US sampled.

during the run and progressive cessation during the appearance of milky grains, Reynolds et al., 1999). In contrast, no indication of irrigation has been found in Chobareti, but a drier climate between 3300 and 2900 cal. BC.

Although still insufficient evidence for a clear irrigation practice in the current specific case, the Gadachrili and Chobareti data provide additional palaeoclimatic indications consistent with the regional palynological results obtained in Paravani (Messager et al., 2013), Zarishat (Joannin et al., 2014), and Vanevan (Leroyer et al., 2016).

The triangle between the delta of the Tigris and the Euphrates, Armenia, and the Syrian coast is the scene of the first major development of techniques in water management at least since the fourth millennium BC (Viollet, 2004). Clear evidence of early agriculture and viticulture in the Shulaveri settlements of Georgia has already been reported (Connor, 2006; McGovern et al., 2017). Although the different crops highlighted do not necessarily require a significant water supply, the question of irrigation remains unresolved. Winter cereals, mainly barley and wheat, that form a basis for the subsistence of pre and protohistoric societies, require a supply of water at the end of winter and spring (Sherrat, 1980), which nature cannot always provide. This is why the practice of artificial irrigation came probably very early to supplement the expectation of natural phenomena such as rain or floods. "Irrigation ditches" have already been identified very close to the sites of Imiris Gora and Aruchlo in former studies (Mardaleishvili and Janelidze, 1984; Connor, 2006). In each of these cases, the dating of the formations, the nature of the sedimentary facies (see section descriptions in the supplementary material), the Hjulström values obtained and the distance from the river to the sites (Fig. 13 and Suchodoletz and Faust, 2017), allow us to exclude a possible wetland drainage function for these channels. In the case of Gadachrili or Mentesh Tepe, this is the first time that this type of hydraulic structure is studied and calibrated chronologically by absolute dating. We also assume that if the canals were used for irrigation practices it was mostly to increase and secure yields (spring watering, regular water intake limiting water stress) as part of a windfall effect related to the 8.2 ka climate change event.

Currently located in the vicinity of non-perennial streams, the sites of Gadachrili and Mentesh Tepe have nevertheless archaeological channels that have been fed by the diversion of river courses in which water circulated in the Neolithic. Through these two examples and the dating obtained on these different sites, it is attractive to consider a wet period accompanying and following the 8.2 ka climatic event ( $6.2 \mathrm{cal}$. BC) during almost a millennium, starting at least at $6622 \mathrm{cal}$. BC and probably ending around 5683 cal. BC. Until now, no other region of the Lesser Caucasus appears to present this type of water management structure for the Early Neolithic. Moreover, and according to the abundant international literature on this subject, the case of Gadachrili, and to a lesser extent of Mentesh Tepe, could be considered as the oldest water management structure actually discovered. 


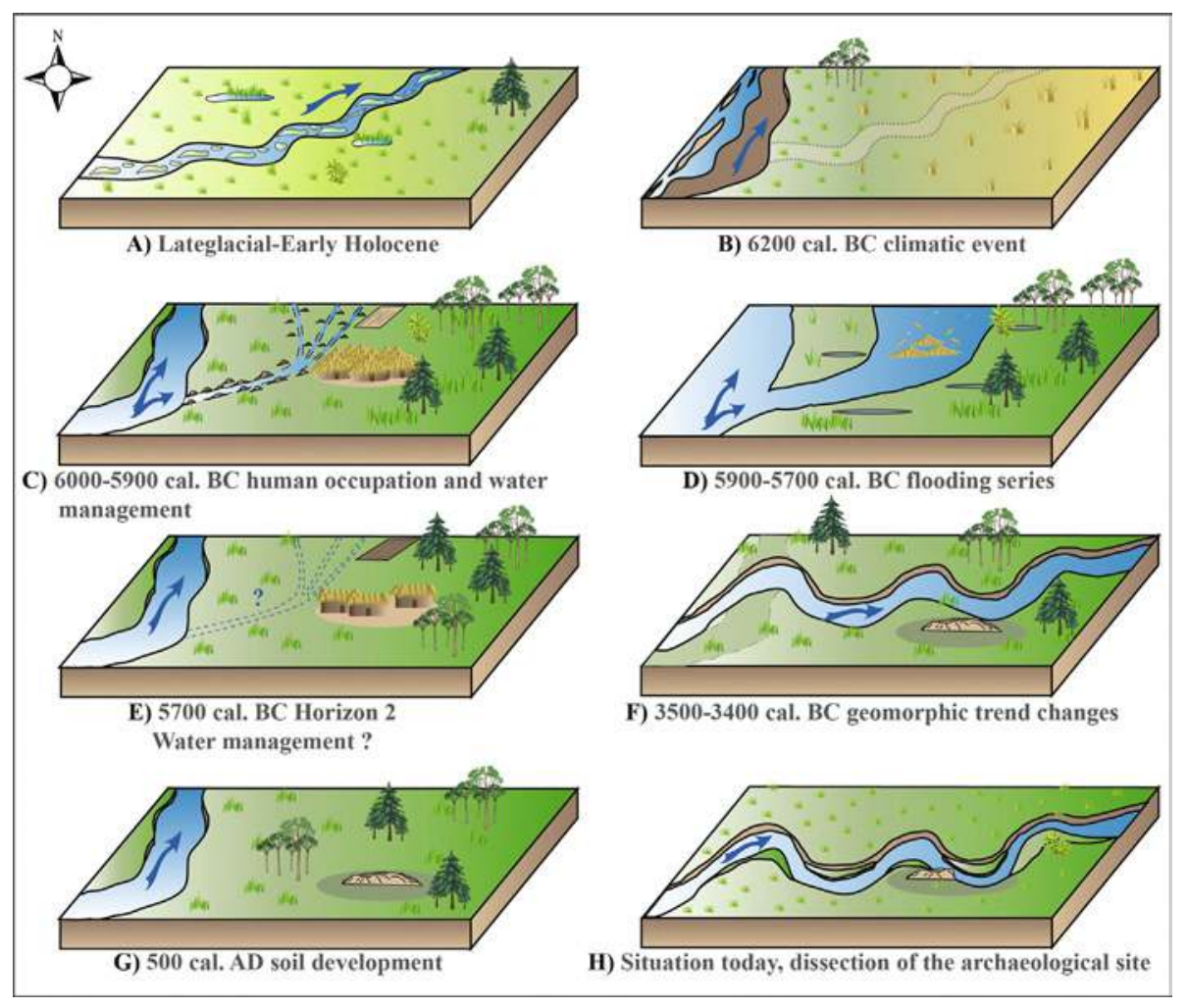

Fig. 15. Kinematics of the main Postglacial landscape evolution stages of the Gadachrili Gora site.

\subsection{The potential impact of water management on the current} hydrological behaviour of the Shulaveri river

As suggested in the recent geomorphological study of the lower Shulaveri Ghele by Suchodoletz and Faust (2017), lack of direct water access for the local Neolithic settlements would make possible the existence of water management structures for their water supply as formerly hypothesised for Imiris Gora and Aruchlo (Javakhishvili, 1973; Kiguradze, 1986; Hansen and Mirtskhulava, 2012). As observed in some studies, the freshwater canals could easily become new channels (Doolittle, 1980 \& 2006) during high intensity flood episodes. In the case of Gadachrili, it is suggested that this type of process has occurred at least once during the use of the channel and one or more times after its abandonment. As recently supposed (Suchodoletz and Faust, 2017), the existence of water management structures in Gadachrili and possibly in the surrounding sites (Imiris Gora, Shulaveris Gora, notably) could be one of the retroactive causes of the Shulaveri river channel migration. The forcing associated with these changes could have been relatively small, implying the existence of underlying tipping points where self-propelling change - i.e. strong positive feedbackis triggered within the systems in question (Turney et al., 2016). The Shulaveri river valley seems to be, potentially, highly-sensitive to changes caused by the passing of tipping points within different components of the climate, geomorphic system, and past anthropogenic activities. In this context several aspects concerning the multiple geomorphic factors and responses in the landscape reconstruction must be investigated, especially since the incision giving rise to the current Shulaveri river seems to be recent (posterior to $1500 / 1900 \mathrm{BP}$, ca $500 \mathrm{cal}$. AD), indicating powerful but long retroactive phenomena in response to weak disturbances of this specific mountain hydrosystem (partly related to the Derbent lowstand of the Caspian Sea around 500 cal. AD, Sauer et al., 2013).

\section{Conclusions}

The interdisciplinary data involved in the study of Gadachrili deliver new results integrated into the framework of past investigations conducted in geomorphology, archaeology, and palaeoecology in the Lesser Caucasus (Ollivier et al., 2010; Joannin et al., 2010; Lyonnet et al., 2012; Messager et al., 2013; Chataigner et al., 2014). Geomorphic response and bioclimatic changes are coupled with Neolithic land use to refine the interaction between the Caucasian societies and the evolution of their environment. Our preliminary data sets indicate that the river management was established around $5900 \mathrm{cal}$. BC and presumably led to Gadachrili village flooding as well as the destruction and local abandonment of the hydraulic infrastructures between 5750 and 5430 cal. BC. These features were developed during the more humid period following the $8200 \mathrm{cal}$. BP (6200 cal. BC) climatic event in the region. The question of the reality of irrigation practices in Gadachrili and their probable link with potential humid climatic components is complex and still needs further study. If there was irrigation, this was probably practiced to optimize agricultural yield. Important work in geoarchaeology (and in agronomy) remains to be done on all Neolithic sites studied and their environment in this region (as also shown for Mentesh Tepe in Azerbaijan). The development of water management in this area probably weakened the balance of the Shulaveri hydrosystem in the long term. This transition from the destabilisation threshold could continue to produce its effects until today. If this is the case, it would be a perfect example of the impact of the transition from a natural geosystem to an anthropised geosystem, this, since the beginning of the Neolithic. The major adjustments necessary for hydraulic farming systems (construction and maintenance of canals) require new forms of social organisation adapted to the management of an agricultural activity.

The study of these new practices accompanying the rise of the 


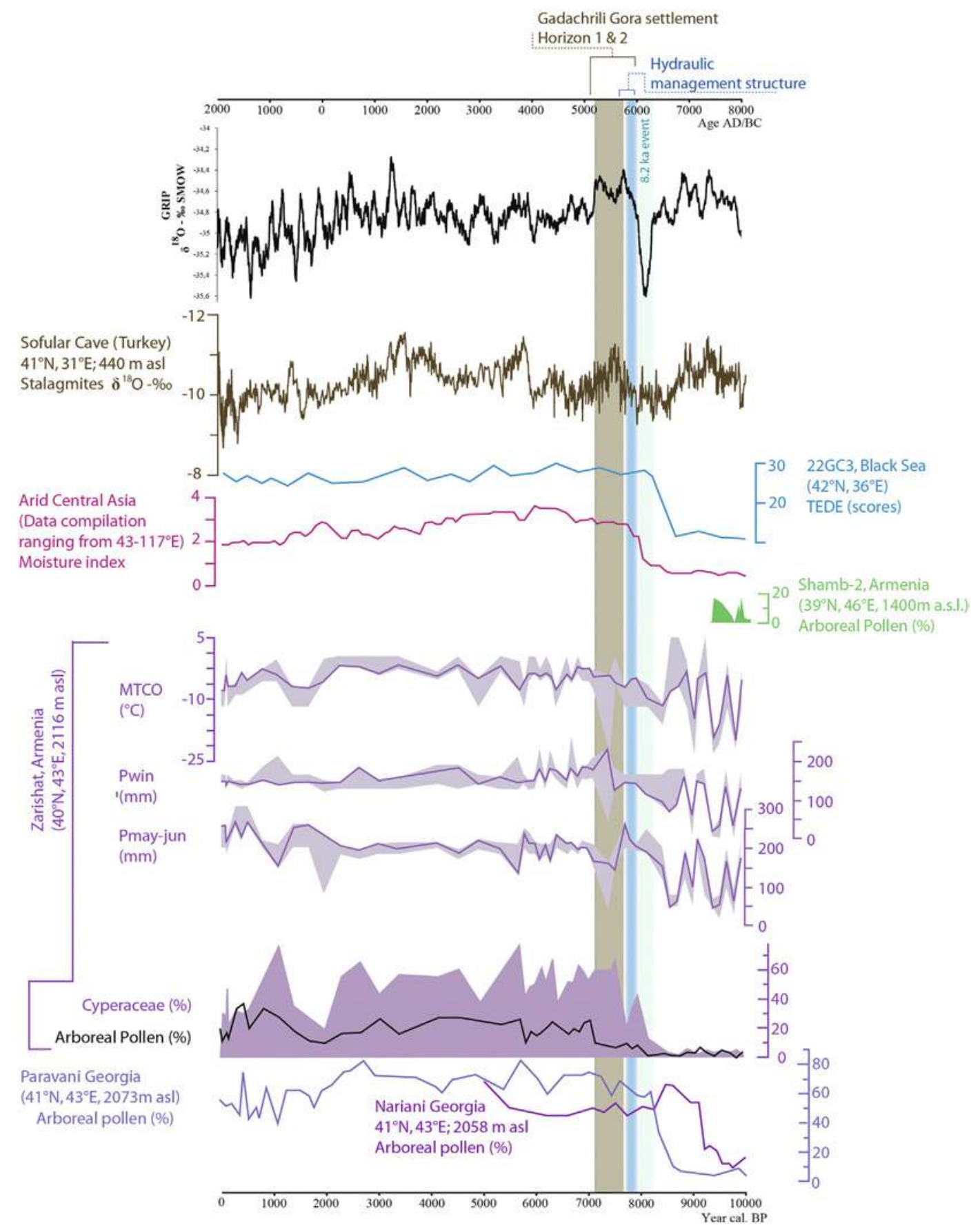

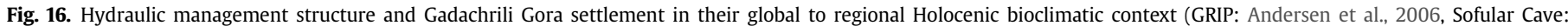

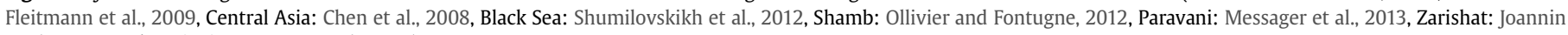
et al., 2014, and Nariani: Messager et al., 2017).

Neolithic between Europe and Asia finds a particular echo in Gadachrili (and to a lesser extent in Mentesh Tepe). The development of multidisciplinary research on Holocene societies and environments in the Lesser Caucasus highlights the significant character of this region of Georgia in the study of recent prehistory.

\section{Acknowledgements}

This work was funded by the ANR ORIMIL (ANR-12-JSH3-0003) and the ANR-DFG KURA IN MOTION! (ANR-12-FRAL-0011) and the CNRS (LIA GATES). Scientific, technical, and financial support were also provided by the French-Armenian LIA NHASA (Natural Hazards and Adaptation Strategies in Armenia from 10000 BC onwards), as well as the Labex OT MED program GEOART and the AMIDEX Water Traces program. We are grateful to B. Berthier, J.P. Dumoulin and C. Moreau for LMC14-AMS facilities and to C. Gautier for stable isotope measurements. Special thanks are due to B. Lyonnet and her team (Azerbaijan \& France) for the work done in Mentesh Tepe; Azerbaijan, as well as G. Goude for the statistical treatment and the discussion on the isotopic analysis. We are also very grateful to the Tbilissi Museum as well as K. Bastert-Lamprichs and S. Hansen from the DAI (Berlin) and his team working in Aruchlo, Georgia. We also 
want to credit the reviewers for their very useful comments.

\section{References}

Adams, R. MCc, 1974. Historic patterns of Mesopotamian irrigation agriculture. In Downing, T.E., Gibson, McG. (Eds.), Irrigation's Impact on Society, Anthropological Papers of the University of Arizona, N 25. The University of Arizona Press, Tucson, pp. 1-6, 1974.

U.S. Agency for International Development \& Development Alternatives Inc, 2002. Water Management in the South Caucasus, Integrated River Basin PlanningKhrami/Debed Watershed, Final Report, p. 199.

Andersen, K.K., Svensson, A., Johnsen, S.J., Rasmussen, S.O., Bigler, M. Rothlisberger, R., Ruth, U., Siggaard-Andersen, M.-L., Peder Steffensen, J., DahlJensen, D., Vinther, B.M., Clausen, H.B., 2006. The Greenland Ice Core Chronology 2005. 15-42ka. Part 1: constructing the time scale. Quat. Sci. Rev. 25 3246-3257.

Araus, J., Febrero, A., Buxó, R., Camalich, M., Martin, D., Molina, F., RodriguezAriza, M., Romagosa, I., 1997a. Changes in carbon isotope discrimination in grain cereals from different regions of the western Mediterranean basin during the past seven millennia: palaeoenvironmental evidence of a differential change in aridity during the late Holocene. Global Change Biol. 3, 107-118.

Araus, J., Febrero, A., Buxó, R., Rodríguez-Ariza, M., Molina, F., Camalich, M. Martín, D., Voltas, J., 1997b. Identification of ancient irrigation practices based on the carbon isotope discrimination of plant seeds: a case study from the south-East iberian peninsula. J. Archaeol. Sci. 24, 729-740.

Arnaud-Fassetta, G., Beltrando, G., Fort, M., Plet, A., André, G., Clément, D., Dagan, M., Mering, C., Quisserne, D., Rycx, Y., 2002. The catastrophic flood of November 1999 in the Argent Double catchment (Aude, France): a case for reassessing the management of pluvial and fluvial hazards in the context of infrequent rainfall events. Géomorphol. Relief, Process. Environ. 8 ( $\left.n^{\circ} 1\right), 17-33$

Aurenche, O., 1982. Préhistoire des sociétés hydrauliques du Proche Orient ancien. In: L'Homme et l'eau en Méditerranée at au Proche Orient. II. Aménagements hydrauliques, Etat et législation. Maison de l'Orient et de la Méditerranée Jean Pouilloux, pp. 31-44.

Badalyan, R., Harutyunyan, A., Chataigner, C., Le Mort, F., Chabot, J., Brochier, J.E. Balasescu, A Radu, V Hovsepyan, R, 2010. The settlement of AknashenKhatunarkh. A neolithic site in the Ararat plain (Armenia): excavation Results 2004e2009. TÜBA-AR 13 (2010), 185e218.

Benkova, V.E., Schweingruber, F.H., 2004. Anatomy of Russian wood. An Atlas for the Identification of Tree, Shrubs, dwarf Shrubs and Woody Lianas from Russia. Swiss Federal Institute for Forest, Snow and Landscape Research, Haupt, Bern, p. 456.

Berger, J.F. Guilaine, J., 2008. The 8200 cal BP abrupt environmental change and the Neolithic transition: a Mediterranean perspective. Quat. Int. 200, 31-49.

Bishop, A.A., Marvin, J.E., Warren, H.A., 1967. Surface irrigation systems. In: Hagan, R.M., Haise, H.R., Edminster, T.W. (Eds.), Irrigation of Agricultural Lands. Agronomy, No. 11, pp. 865-884.

Bonham-Carter, G.F., 1965. A numerical method of classification using qualitative and semi-quantitative data, as applied to the facies analysis of limestones. Bull. Can. Petrol. Geol. 13 (4), 482-502.

Bronk Ramsey, C., Lee, S., 2013. Recent and planned developments of the program OxCal. Radiocarbon 55 (2-3), 720-730.

Cappers, R.T.J., Bekker, R.M., 2013. A Manual for the Identification of Plant Seeds and Fruits. Barkhuis. Groningen University Library, Groningen, p. 273.

Cappers, R.T.J., Neef, R., Bekker, R.M., 2009. Digital Atlas of Economic Plants. Volumes 1 and 2, vol. 527. Groningen Institute of Archaeology, the Deutsches Archäologisches Institut, Groningen, Berlin, p. 1508.

Cauvin, J., 1978. Les premiers villages de Syrie-Palestine du IXème au VIIème millénaires, Collection de la Maison de l'Orient méditerranéen. Archaeol. 4, 172.

Chataigner, C., Badalyan, R., Arimura, M., 2014. The Neolithic of the Caucasus. Oxford Handbooks Online, p. 39.

Chen, F., Yu, Z., Yang, M., Ito, E., Wang, S., Madsen, D.B., Huang, X., Zhao, Y., Sato, T. Birks, H.J.B., Boomer, I., Chen, J., An, C., Wuennemann, B., 2008. Holocene moisture evolution in arid central Asia and its out-of-phase relationship with Asian monsoon history. Quat. Sci. Rev. 27, 351-364.

Church, M., Gilbert, R., 1975. Proglacial fluvial and lacustrine environments. In: Jopling, A.V., Mac Donald, B.C. (Eds.), Glaciofluvial and Glaciolacustrine Sedimentation, Soc. Of Econ. Paleontol. \& Mineral, vol. 23. Sp. Publ., pp. 22-100

Connor, S.E., 2006. A Promethean Legacy: Late Quaternary Vegetation History of Southern Georgia, Caucasus. PhD Thesis. Faculty of Arts, Social and Environmental Enquiry, University of Melbourne, p. 342.

Coombes, P., Barber, K., 2005. Environmental determinism in Holocene research: causality or coincidence? Area 37, 303-311.

Costa, J.E., 1983. Palaeohydraulic reconstruction of flashflood peaks from boulder deposits in the Colorado front range. Geol. Soc. Am. Bull. 94, 986-1004.

Courcier, A., 2010. Les débuts de la métallurgie dans les pays du Caucase, de la fin du VIe au milieu du IIIe millénaire avant notre ère : recherches sur leur origine d'après le potentiel métallifère, l'analyse d'objets et les relations observées avec les régions voisines. $\mathrm{PhD}$ Université Panthéon-Sorbonne, Paris, p. 1082.

Davis, B.A.S., Brewer, S., Stevenson, A.C., Guiot, J., 2003. The temperature of Europe during the Holocene reconstructed from pollen data. Quat. Sci. Rev. 22, 1701-1716.

Délibrias, G., 1985. Le carbone 14. In: Roth, E., Poty, B. (Eds.), ,Méthodes de datation par les phénomènes nucléaires naturels: applications. Collection CEA. Masson, Paris, pp. 421-458.

Doolittle, W.E., 1980. Aboriginal agricultural development in the valley of sonora, Mexico. Geogr. Rev. 70, 328-342.

Doolittle, W.E., 2006. Agricultural manipulation of floodplains in the southern basin and range province. Catena 65, 179-199.

Doolittle, W.E., 2011. Canal Irrigation in Prehistoric Mexico: the Sequence of Technological Change. University of Texas Press, p. 219.

Fleitmann, D., Cheng, H., Badertscher, S., Edwards, R.L., Mudelsee, M., Göktürk, O.M., Fankhauser, A., Pickering, R., Raible, C.C., Matter, A., Kramers, J., Tüysüz, O. 2009. Timing and climatic impact of Greenland interstadials recorded in stalagmites from northern Turkey. Geophys. Res. Lett. 36, L19707 https://doi.org/ 10.1029/2009GL040050.

Flohr, P., Muldner, G., Jenkins, E., 2011. Carbon stable isotope analysis of cereal remains as a way to reconstruct water availability: preliminary results. Water History 3 (2), 121-144. https://doi.org/10.1007/s12685-011-0036-5. ISSN 18777244.

Fujii, S., 2007. Wadi abu tulayha and wadi ruweishid ash-sharqi: an investigation of PPNB barrage systems in the jafr basin. Neo-Lithics 2/07, 6-17.

Gauthier, C., Hatté, C., 2008. Effects of handling, storage, and chemical treatments of $\delta^{13} \mathrm{C}$ values of terrestrial fossil organic matter. G-cubed 9, Q08011. https:// doi.org/10.1029/2008GC001967.

Guliyev, F., Nishiaki, Y., 2010. Excavations at the neolithic settlement of goytepe, the middle Kura valley, Azerbaijan, 2008-2009. In: Matthews, R., Curtis, J. (Eds.), Proceedings of 7th ICAANE, Vol. 3: Fieldwork and Recent Research. Harrassowitz Verlag, Wiesbaden, pp. 71-84.

Hamon, C., 2008. From neolithic to chalcolithic in the southern Caucasus: economy and macrolithic implements from shulaveri-shomu sites of kwemo-kartli (Georgia). Paleorient 34 (2), 85-135.

Hamon, C., Jalabadze, M., Agapishvili, T., Baudoin, E., Koridze, I., Messager, E., 2016. Gadachrili Gora: architecture and organization of a neolithic settlement in the middle Kura valley ( $6^{\text {th }}$ millennium BC, Georgia). Quat. Int. 395, 154-169.

Hansen, S., Mirtskhulava, G., 2012. The neolithic settlement of Aruchlo. In: Report on the Excavations in 2009-2011. AMIT, Archäologische Mitteilingen aus Iran und Turan, pp. $58-86$ n $^{\circ} 44$.

Hansen, S., Mirtskhulava, G., 2017. Excavations in Aruchlo 2005-2014. In: Kura Projects, The (Ed.), New Research on the Later Prehistory of the Southern Caucasus, Archäologie in Iran und Turan, Band, vol. 16, pp. 195-201.

Hansen, S., Ulrich, M., 2017. Report on the 2012-2014 excavation campaign in Aruchlo. In: The Kura Projects. New Research on the Later Prehistory of the Southern Caucasus. Verlag Berlin, pp. 201-222. Archäologie in Iran und Turan, 16.

Hassan, F., 2011. Water History for Our Times, IHP Essays on Water History. UNESCO, p. 122. International Hydrological Program.

Hatté, C., Fontugne, M., Rousseau, D.D., Antoine, P., Zöller, L., Tisnerat-Laborde, N. Bentaleb, I., 1998. $\delta^{13} \mathrm{C}$ variations of loess organic matter as a record of the vegetation response to climatic changes during the Weichselian. Geology 26, $583-586$.

Hatté, C., Antoine, P., Fontugne, M., Lang, A., Rousseau, D.D., Zöller, L., 2001a. $\delta^{13} \mathrm{C}$ of loess organic matter as a potential proxy for paleoprecipitation reconstruction. Quat. Res. 55, 33-38.

Hatté, C., Pessenda, L.C., Lang, A., Paterne, M., 2001b. Development of accurate and reliable ${ }^{14} \mathrm{C}$ chronologies for loess deposits: application to loess sequence of Nussloch (Rhine Valley, Germany). Radiocarbon 43, 611-618.

Helwing, B., Aliyev, T., 2017. Excavations in the mil plain sites, 2012-2014. In: The Kura Projects. New research on the later Prehistory of the Southern Caucasus. Archäologie in Iran und Turan, 16. Verlag Berlin, pp. 11-42.

Hjulström, F., 1935. Studies of the morphological activity of rivers as illustrated by the river Fyris. Bull. Geol. Inst. 25, 221-527. University of Uppsala.

Huckleberry, G., 1999. Stratigraphic identification of destructive floods in relict canals: a case study from the middle Gila River, Arizona, Kiva. J. SW. Anthropol. Hist. 65 (1), 7-33.

Huckleberry, G., Rittenour, T., 2014. Combining radiocarbon and single-grain optically stimulated luminescence methods to accurately date pre-ceramic irrigation canals, Tucson, Arizona. J. Archaeol. Sci. 41, 156-170.

Huckleberry, G., Hayashida, F. Johnson, J., 2012. New insights into the evolution of an intervalley prehistoric irrigation canal system, north coastal Peru. Geoarcheology Int. J. 27, 492-520.

Jacomet, S., 2006. Identification of Cereal Remains from Archaeological Sites. Archaeobotany Lab, IPAS, Basel University, Bâle, p. 61.

Javakhishvili, A.I., 1973. Construction and Architecture of the Settlements of the Southern Caucasus from the 5th to the 3 Rd Millenium BC, [In Russian.]. Edition Metsnerieba, Tbilisi.

Joannin, S., Cornée, J.-J., Munch, P., Fornari, M., Vassiliev, J., Krijgsman, W., Nahapetyan, S., Gabryelian, Y., Ollivier, V., Roiron, P., Chataignier, C., Suc, J.-P., 2010. Early Pleistocene climatic cycles in continental deposits of the Lesser Caucasus of Armenia inferred from palynology, magnetostratigraphy, and 40 $\mathrm{Ar}$ 39Ar dating of volcanic tufs. Earth Planet Sci. Lett. 149-158.

Joannin, S., Ali, A.A., Ollivier, V., Roiron, P., Peyron, O., Chevaux, S., Nahapetyan, S., 
Tozalakyan, P., Karakhanyan, A., Chataigner, C., 2014. Vegetation, fire and climate history of the Lesser Caucasus: a new Holocene record from Zarishat fen (Armenia). J. Quat. Sci. 29 (1), 70-82.

Kiguradze, T., 1986. Neolithische Siedlungen von Kvemo-Kartli, Georgien (Materialen zur Allgemeinen und Vergleichenden Archäologie 29). Verlag C.H. Beck, München.

Koster, E.H., 1978. Transverse ribs: their characteristics, origin and palaeohydraulic significance. In: Miall, A.D. (Ed.), Fluvial Sedimentology, Canadian Association of Petroleum Geology, Mem, vol. 5, pp. 161-186.

Kvinikadze, M., Kuparadze, D., Kerestedjian, T., Sirbiladze, I., 2006. Geoecological assessment of the environment: an example from the territory of Georgia. Geochem. Mineral Petrol. 44, 131-140. Sofia.

Lang, A., Hatté, C., Rousseau, D.D., Antoine, P., Fontugne, M., Zöller, L., Hambach, U., 2003. High resolution chronology for loess: comparing AMS ${ }^{14} \mathrm{C}$ and optical dating results. Quat. Sci. Rev. 22, 953-959.

Leroy, S.A.G., Kakroodi, A.A., Kroonenberg, S.B., Lahijani, H.A.K. Alimohammadian, H., Nigarov, A., 2013a. Holocene vegetation history and sea level changes in the SE corner of the Caspian Sea: relevance to SW Asia climate. Quat. Sci. Rev. 70, 28-47.

Leroy, S.A.G., Tudryn, A., Chalié, F., López-Merino, L., Gasse, F., 2013b. From the Allerød to the mid-Holocene: palynological evidence from the south basin of the Caspian Sea. Quat. Sci. Rev. 78, 77-97.

Leroyer, C., Joannin, S., Aoustin, D., Ali, A.A., Peyron, O., Ollivier, V., Tozalakyan, P., Karakhanyan, A., Jude, F., 2016. Mid Holocene vegetation reconstruction from Vanevan peat (eastern shore of Lake Sevan; Armenia). Quat. Int. 395, 5-19.

Ancient Kura 2010e2011: the First Two Seasons of Joint Field Work in the Southern Caucasus, 44. In: Lyonnet, B., Guliev, F., Helwing, B., Aliyev, T., Hansen, S. Mirtskhulava, G. (Eds.), 2012. Archeaologische Mitteilungen aus Iran und Turan, pp. 1-190.

Lyonnet, B., Guliyev, F., Bouquet, L., Bruley-Chabot, G., Samzun, A., Pecqueur, L., Jovenet, E., Baudouin, E., Fontugne, M., Raymond, P., Degorre, E., Astruc, L. Guilbeau, D., Le Dosseur, G., Benecke, N., Hamon, C., Poulmarc'h, M., Courcier, A., 2016. Mentesh Tepe, an early settlement of the shomu-shulaveri culture in Azerbaijan. Quat. Int. 395, 170-183.

Lyonnet, B., Guliyev, F., Baudouin, E., Bouquet, L., Bruley-Chabot, G., Samzun, A., Fontugne, M., Degorre, E., Husson, X., Raymond, P., 2017. Mentesh Tepe (Azerbaijan), a preliminary report on the 2012-2014 excavation. In: The Kura Projects. New research on the later Prehistory of the Southern Caucasus. Archäologie in Iran und Turan, vol. 16. Verlag Berlin, pp. 125-140.

Malkowski, K., Hoffman, A., 1979. Semi-quantitative facies model for the kapp, starostin formation (permian), spitsgerben. Acta Palaeontol. Pol. 24 (2), 217-230.

Mardaleishvili, R.K., Janelidze, C.P., 1984. Sravitel'nyi analiz diagnosticheskikh pokazatelei sovremennykh i Golotsenovykh pogrebennykh pochv Marneulskoi Pavniny. In: Chubinishvili, T.N. (Ed.), Chelovek I Okruzhaiushchaia Ego Sreda: Materialy Po Arkheologii Gruzii I Kavkaza, pp. 89-91.

McGovern, P., Jalabadze, M., Batiuk, S., Callahan, M.P., Smith, K.E., Hall, G.R., Kvavadze, E., Maghradze, D., Rusishvili, N., Bouby, L., Failla, O., Cola, G. Mariani, L., Boaretto, E., Bacilieri, R., This, P., Wales, N., Lordkipanidze, D., 2017. Early neolithic wine of Georgia in the south Caucasus, PNAS. Proc. Natl. Acad. Sci. U.S.A. https://doi.org/10.1073/pnas.1714728114.

McLaren, P., Bowles, D., 1985. The effects of sediment transport on grain-size distributions. J. Sediment. Petrol. 55 (4), 457-470.

Messager, E., Belmecheri, S., Von Grafenstein, U., Nomade, S., Ollivier, V., Voinchet, P., Puaud, S., Courtin- Nomade, A., Guillou, H., Mgeladze, A., Dumoulin, J.-P., Mazuy, A., Lordkipanidze, D., 2013. Late quaternary record of the vegetation and catchment-related changes from lake Paravani (javakheti, south Caucasus). Quat. Sci. Rev. 77, 125-140.

Messager, E., Herrscher, E., Martin, L., Kvavadze, E., Martkoplishvili, I., Delhon, C., Kakhiani, K., Bedianashvili, G., Sagona, A., Bitadze, L., et al., 2015. Archaeobotanical and isotopic evidence of Early Bronze Age farming activities and diet in the mountainous environment of the South Caucasus: a pilot study of Chobareti site (Samtskhe-Javakheti region). J. Archaeol. Sci. 53, 214-226.

Messager, E., Nomade, N., Wilhelm, B., Joannin, S., Scao, V., Von Grafenstein, U., Martkoplishvili, I., Ollivier, V., Mgeladze, A., Dumoulin, J.P., Mazuy, A., Lordkipanidze, D., 2017. New pollen evidence from Nariani (Georgia) for delayed postglacial forest expansion in the South Caucasus. Quat. Res. 87, $121-132$.

Miall, A.D., 1988. Reservoir heterogeneities in fluvial sandstones - lessons learned from outcrop studies. AAPG (Am. Assoc. Pet. Geol.) Bull. 72 (6), 682-697.

Mithen, S., 2010. The domestication of water: water management in the ancient world and its prehistoric origins in the Jordan Valley. Phil. Trans. Roy. Soc. 368, 5249-5274.

Montoya, C., Balasescu, A., Joannin, S., Ollivier, V., Liagre, J., Nahapetyan, S., Ghukasyan, R., Colonge, D., Gasparyan, B., Chataigner, C., 2013. The upper paleolithic site of kalavan 1 (Armenia): an epigravettian settlement in the lesser Caucasus. J. Hum. Evol. 621-640.

Morrill, C., Jacobsen, R.M., 2005. How widespread were climate anomalies 8200 years ago? Geophys. Res. Lett. 32, 1-4.

Mosar, J., Kangarli, T., Bochud, M., Glasmacher, U.A., Rast, A., Brunet, M.F., Sosson, M., 2010. Cenozoic-recent tectonics and uplift in the greater Caucasus: a perspective from Azerbaijan. Geol. Soc. 340, 261-280. London. Special publications.

Nakhutsrishvili, G., 2012. The Vegetation of Georgia (South Caucasus). Springer Science \& Business Media, p. 236.
Neef, R., Cappers, R.T.J., Bekker, R.M., 2011. Digital Atlas of Economic Plants in Archaeology. Groningen Institute of Archaeology (University of Groningen), Deutsches Archäologisches Institut, Groningen, Berlin, p. 274.

Neill, C.R., 1967. Mean-velocities criterion for scour of coarse uniform bed-material. In: International Association of Hydrological Research, 12th Proceeding, Fort Collins, Colorado, vol. 3, pp. 46-54.

Neill, C.R., 1968. A Re-examination of the Beginning of Movement for Coarse Granular Bed Material, Walling-ford Hydraulics Research Station, p. 37. Report 68.

Nesbitt, M., Goddard, J., 2006. Identification Guide for Near Eastern Grass Seeds. Institute of Archaeology, University College London, London, p. 144.

O'Leary, M.H., 1988. Carbon isotopes in photosynthesis. Bioscience 38, 328-336.

Ollivier, V., 2009. Continuités, instabilités et ruptures morphogéniques en Provence depuis la dernière glaciation. In: Travertinisation, détritisme et incisions sur le piémont sud du Grand Luberon (Vaucluse, France). Relations avec les changements climatiques et l'anthropisation, Sans Papier French Studies Program. Cornell University, New York, USA. http://www.einaudi.cornell.edu/french studies/publications/theses.asp? pubid $=4392$.

Ollivier, V., in press. Multiple Geomorphic factors and response in the landscape reconstruction of Aknashen archaeological site (Arax Valley, Armenia). Archaeopress

Ollivier, V., Fontugne, M., 2012. Holocene Landscape and Human Mode of Occupation in the Kura valley (Azerbaijan). AMIT, Archäologische Mitteilingen aus Iran und Turan, pp. 121-127 n 44.

Ollivier, V., Nahapetyan, S., Roiron, P., Gabrielyan, I., Gasparyan, B., Chataigner, C., Joannin, S., Cornée, J.-J., Guillou, H., Scaillet, S., Munch, P., Krijgsman, W., 2010. Quaternary volcano-lacustrine patterns and paleobotanical data in South Armenia. Quat. Int. 223-224, 312-326.

Ollivier, V., Joannin, S., Roiron, P., Nahapetyan, S., Chataigner, C., 2011. Travertinization and Holocene Morphogenesis in Armenia: a reading Grid of Rapid Climatic Changes Impact on the Landscape and Societies between 9500-4000 Cal. $\mathrm{BP}$ in the Circumcaspian Regions? The European Archaeologist (TEA), publication of the European Association of Archaeologists, pp. 26-31 n 36

Ollivier, V., Fontugne, M., Lyonnet, B., 2015. Geomorphic response and ${ }^{14} \mathrm{C}$ chronology of base level changes induced by Late Quaternary Caspian Sea mobility (middle Kura Valley, Azerbaijan). Geomorphology 230, 109-124.

Ollivier, V., Fontugne, M., Lyonnet, B., Chataigner, C., 2016. Base level changes, river avulsions and Holocene human mode of occupations in the Caspian Sea area (middle Kura valley, South Caucasus). Quat. Int. 395, 79-94.

Parsa Pajouh, D., Schweingruber, F.H., Lenz, O., 2001. Atlas des bois du nord de l'Iran. Description anatomique et identification microscopique des essences principales. Tehran University Publications, Tehran, p. 144.

Peel, M.C., Finlayson, B.L., McMahon, T.A., 2007. Updated world map of the KöppenGeiger climate classification. Hydrol. Earth Syst. Sci. 11, 1633-1644.

Petit, F., 1988. Phénomènes influençant la mise en mouvement et le transport des particules en rivières naturelles. Z. Geomorphol. 32 (3), 299-310.

Pross, J., Kotthoff, U., Müller, U.C., Peyron, O., Dormoy, I., Schmiedl, G., Kalaitzidis, S. Smith, A.M., 2009. Massive perturbation in terrestrial ecosystems of the Eastern Mediterranean region associated with the 8.2 kyr B.P. climatic event. Geology 37 (10), 887-890.

Purdue, L., Berger, J.-F, 2015. An integrated socio-environmental approach to the study of ancient water systems: the case of prehistoric Hohokam irrigation systems in semi-arid central Arizona. J. Archaeol. Sci. 53, 586-603.

Rasmussen, S.O., Bigler, M., Blockley, S.P., Blunier, T., Buchardt, S.L., Clausen, H.B. Cvijanovic, I., Dahl-Jensen, D, Johnsen, S.J., Fischer, H., Gkinis, V., Guillevic, M. Hoek, W.Z., Lowe, J.J., Pedro, J.B., Popp, T., Seierstad, I.K., Steffensen, J.P. Svensson, A.M., Vallelonga, P., Vinther, B.M., Walker, M.J.C., Wheatley, J.J., Winstrup, M., 2014. A stratigraphic framework for abrupt climatic changes during the Last Glacial period based on three synchronized Greenland ice-core records: refining and extending the INTIMATE event stratigraphy. Quat. Sci. Rev. 106, 14-28.

Reimer, PJ., Bard, E., Bayliss, A., Beck, J.W., Blackwell, P.G., Bronk Ramsey, C. Buck, C.E., Cheng, H., Edwards, R.L., Friedrich, M., Grootes, P.M., Guilderson, T.P. Haflidason, H., Hajdas, I., Hatté, C., Heaton, T.J., Hoffman, D.L., Hogg, A.G. Hughen, K.A., Kaiser, K.F., Kromer, B., Manning, S.W., Niu, M., Reimer, R.W. Richards, D.A., Scott, E.M., Southon, J.R., Staff, R.A., Turney, C.S.M., van de Plicht, J., 2013. IntCal13 and Marine13 radiocarbon age calibration curves 0-50,000 years cal BP. Radiocarbon 55 (4), 1869-1887.

Renssen, H. Goosse, H. Fichefet, T, 2002. Modeling the effect of freshwater pulses on early Holocene climate: the influence of highfrequency variability. Paleoceanography $17,10.1-10.18$.

Reynolds, M.P., Rajaram, S., Sayre, K.D., 1999. Physiological and genetic changes of irrigated wheat in the post-green revolution period and approaches for meeting projected global demand. Crop Sci. 39-6, 1611-1621.

Sauer, E., Wilkinson, T.J., Rekavandi, H.O., Nokandeh, J. (Eds.), 2013. Persia's imperial Power in Late Antiquity: the Great Wall of Gorgan and the Frontier Landscapes of Sasanian Iran, British Institute of Persian Studies Archaeological Monographs, vol. 2. Oxbow, Oxford \& Oakville (CT), p. 712

Schweingruber, F.H., 1990. Anatomie Europaischer Hölfzer - Anatomy of European Woods. Swiss Federal Institute for Forest, Snow and Landscape Research, Birmensdorf, Haupt, Bern, Stuttgart, p. 800.

Schweingruber, F.H., Börner, A., Schulze, E.-D., 2011. Atlas of Stem Anatomy in Herbs, Shrubs and Trees, vol. 1. Springer-Verlag, Berlin, p. 495.

Sherrat, A., 1980. Water, soil and seasonality in early cereal cultivation. World Archaeol. 11 (3), 313-330. 
Shumilovskikh, L.S., Tarasov, P., Arz, H.W., Fleitmann, D., Marret, F., Nowaczyk, N., Plessen, B., Schlütz, F., Behling, H., 2012. Vegetation and environmental dynamics in the southern Black Sea region since $18 \mathrm{kyr}$ BP derived from the marine core 22-GC3. Palaeogeogr. Palaeoclimatol. Palaeoecol. 337-338, 177-193.

Soutter, M., Mermoud, A., Musy, A., 2007. Ingénierie des eaux et du sol : processus et aménagements. Presses Polytechniques et Universitaires Romandes (PPUR), Science et ingénierie de l'environnement, p. 294.

Staubwasser, M., Weiss, H., 2006. Holocene climate and cultural evolution in late prehistoric-early historic West Asia. Quat. Res. 66 (3), 372-387.

Strahler, A.N., 1957. Quantitative analysis of watershed geomorphology. Trans. Am. Geophys. Union 38 (6), 913-920.

Suchodoletz, Hv, Faust, D., 2017. Late Quaternary fluvial dynamics and landscape evolution at the lower Shulaveris Ghele River (southern Caucasus). Quat. Res. https://doi.org/10.1017/qua.2017.80.

Suchodoletz, Hv, GärtnerA, Hoth, S., Umlauft, J., Sukhishvili, L., Faust, D., 2016. Late Pleistocene river migrations in response to thrust belt advance and sedimentflux steering - the Kura River (southern Caucasus). Geomorphology 266, 53-65.

Sundborg, A., 1956. The River Klarälven, a study of fluvial processes. Geogr. Ann. 38 $127-316$.

Sundborg, A., 1967. Some aspect on fluvial sediments and fluvial morphology: 1. General views and graphic methods. Geogr. Ann. 49A, 333-343.

Thomas, E.R., Wolff, E.W., Mulvaney, R., Steffensen, J.P., Johnsen, S...J. Arrowsmith, C., White, J.W.C., Vaughn, B., Popp, T., 2007. The 8.2 ka event from Greenland ice cores. Quat. Sci. Rev. 26, 70-81.

Turney, C.S.M., Brown, H., 2007. Catastrophic early Holocene sea level rise, human migration and the Neolithic transition in Europe. Quat. Sci. Rev. 26, 2036-2041.

Turney, C.S.M., Fogwill, C.J., Lenton, T.M., Jones, R.T., 2016. Tipping points: lessons from the past for the future. Pages Mag. 24, 3.

United Nations, 2011. Second Assessment of Transboundary Rivers, Lakes and Ground Waters, Economic Commission for Europe Convention on the Protection and Use of Transboundary Watercourses and International Lakes. United
Nations Publication, New York and Geneva, p. 448, 2011

Van Andel, T.H., Runnels, C.N., 1995. The earliest farmers in Europe. Antiquity 69, 481-500.

Van Andel, T.H., Zangger, E., Demitrack, A., 1990. Land use and soil erosion in prehistoric and historical Greece. J. Field Archaeol. 17 (4), 379-396.

Vellinga, M., Wood, R.A., 2002. Global climatic impacts of a collapse of the Atlantic thermohaline circulation. Climatic Change 54, 251-267.

Viollet, P.-L., 2004. L'hydraulique dans les civilisations anciennes: 5000 ans d'histoire. Presses de l'Ecole nationale des Ponts et Chaussées, p. 383.

Wallace, M., Jones, G., Charles, M., Fraser, R., Halstead, P., Heaton, T.H.E., Bogaard, A., 2013. Stable carbon isotope analysis as a direct means of inferring crop water status and water management practices. World Archaeol. 45 (3), 388-409. https://doi.org/10.1080/00438243.2013.821671.

Wanner, H., Beer, J., Bütikofer, J., Crowley, T.J., Cubasch, U., Flückiger, J., Goosse, H., Grosjean, M., Joos, F., Kaplan, J.O., Küttel, M., Müller, S.A., Prentice, I.C., Solomina, O., Stocker, T.F., Tarasov, P., Wagner, M., Widmannm, M., 2008. Midto Late Holocene climate change: an overview. Quat. Sci. Rev. 27, 1791-1828.

Weiss, H., Bradley, R.S., 2001. What drives societal collapse? Science 291, 609-610. Weninger, B., Alram-Stern, E., Bauer, E., Clare, L., Danzeglocke, U., Jöris, O.

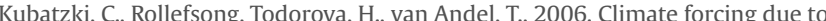
the 8200 cal yr BP event observed at Early Neolithic sites in the eastern Mediterranean. Quat. Int. 66, 401-420.

Whitehead, P., Smith, S.J., Wade, A.J., Mithen, S.J., Finlayson, B.L., Sellwood, B. Valdes, P., 2008. Modelling of hydrology and potential population levels at Bronze Age Jawa, Northern Jordan: a Monte Carlo approach to cope with uncertainty. J. Archaeol. Sci. 35 (3), 517-529.

Wright, J.H.E., Ammann, B., Stefanova, I., Atanassova, J., Margalitadze, N., Wick, L. Blyakharchuk, T., 2003. Lateglacial and early-Holocene dry climates from the Balkan peninsula to Southern Siberia. In: Tonkov, S.B. (Ed.), Aspects of Palynology and Palaeoecology. Pensoft Publishers, Sofia, pp. 127-136.

Wu, T.H., Vyas, S.K., Chang, N.Y., 1973. Probabilistic analysis of seepage: journal of soil mechanics and foundation division. Proc. Am. Soc. Civ. Eng. 99-4, 323-340. 